\title{
Cengiz Han Oğlu Toluy II: Askeri Yaşamı ${ }^{1}$
}

\author{
Burak ÇELIK \\ Arş. Gör., Necmettin Erbakan Üniversitesi, Sosyal ve Beşeri Bilimler Fakültesi, Tarih Bölümü, Konya, Türkiye, \\ celikkburak1@gmail.com (Sorumlu Yazar/Corresponding Author)
}

\begin{tabular}{|c|c|}
\hline Makale Bilgileri & ÖZ \\
\hline $\begin{array}{l}\text { Makale Geçmişi } \\
\text { Geliş: } 16.08 .2020 \\
\text { Kabul: } 17.10 .2020 \\
\text { Yayın: } 25.12 .2020 \\
\text { Anahtar Kelimeler: } \\
\text { Askeri hayat, } \\
\text { Moğol Hanlığı, } \\
\text { Toluy, } \\
\text { Kin Seferi, } \\
\text { Büyük Batı Seferi. }\end{array}$ & $\begin{array}{l}\text { Toluy, Cengiz Hanlığı'nın politik yaşamı içinde doğrudan bulunmasa bile imparatorluğun arka } \\
\text { plandaki en etkili kişisidir. Daha çok askeri alanda faaliyet göstermesi, kısa yaşamı ve ekseriyetle } \\
\text { siyaset alanında öne çıkmış meşhur şahısları anlatmaya ağırlık veren Orta Çağ tarihçilerinin } \\
\text { tutumları nedeniyle, yerli ve yabancı modern araştırmacıların dikkatini en az çeken Moğol } \\
\text { asilzadesidir. Hakkındaki ilk kayıtlara Moğollar'ın Gizli Tarihi adlı eserde } 1203 \text { y1lı olayları } \\
\text { sırasında rastladığımız Toluy'un XIII. yüzyılın başlarında katıldığı Kin Seferi, onun görev aldığ1 } \\
\text { ilk harekâttır. Burada göstermiş olduğu yararlılılar nedeniyle Cengiz Han'dan büyük taltifler } \\
\text { gören Toluy'un, o dönem Otçigin sıfatı taşıması nedeniyle Cengiz Han'ın birinci yardımcıs1 } \\
\text { olduğu, savaşlarda Moğol Ordusunun başkomutanı görevi ile babasının savaş planlarına dahi etki } \\
\text { ettiği zannedilmektedir. Bu nedenle Moğolların devrin süper gücü olmalarında önemli faktörlerden } \\
\text { biri olan askerlik kurumu içinde derin etkiler bıraktığı anlaşılmaktadır. Üç çalışmadan oluşacak } \\
\text { makale dizisinin ikinci bölümü olan bu çalışmada Toluy'un yalnızca askeri faaliyetlerine } \\
\text { değinilmiş, Cengiz ve Ögedey Hanlar zamanında katıldığ1 seferler kronolojik olarak verilerek } \\
\text { anlatılmaya çalışılmıştır. }\end{array}$ \\
\hline
\end{tabular}

\section{Genghis Khan's Son Tolui II: His Military Life}

\begin{tabular}{|c|c|}
\hline Article Info & ABSTRACT \\
\hline $\begin{array}{l}\text { Article History } \\
\text { Received: } 16.08 .2020 \\
\text { Accepted: } 17.10 .2020 \\
\text { Published: } 25.12 .2020 \\
\text { Keywords: } \\
\text { Military life, } \\
\text { Mongol Khanete, } \\
\text { Tolui, } \\
\text { Qin Campaign, } \\
\text { Great West Campaign. }\end{array}$ & $\begin{array}{l}\text { Tolui is the most influential person in the background of the Empire, even if he is not directly } \\
\text { involved in the political life of the Khanate of Genghis. He is the Mongol nobleman who has } \\
\text { attracted the least attention of the local and foreign modern researchers because of his activities in } \\
\text { the military area, his short life and the Middle Ages historians who gave more importance to } \\
\text { explaining the famous people that came to prominence in the field of politics. We come across with } \\
\text { the first records about Tolui in the Secret History of the Mongols during the } 1203 \text { events. Qin } \\
\text { Campaign is the first mission he participated in at the turn of XIII. century. Tolui who saw great } \\
\text { graditude from Genghis Khan because of the usefullness that he has shown in Qin Campaign and it } \\
\text { is thought that he was the first deputy of Genghis Khan due to the fact that he was the commander- } \\
\text { in-chief of the Mongol army during the wars and even influenced his father's war plans. Therefore, } \\
\text { it is thought that the Mongols left deep influences within the military service institution which was } \\
\text { one of the important factors in their becoming superpower of the period. In this study, which is the } \\
\text { second part of a series of articles consisting of three studies, only the military activities of Tolui are } \\
\text { mentioned and the campaigns he participated in during the time of Genghis and Ögedei are tried to } \\
\text { be described in chronological order. }\end{array}$ \\
\hline
\end{tabular}

Atıf/Citation: Çelik, Burak. "Cengiz Han Oğlu Toluy II: Askeri Yaşamı”. Selçuklu Medeniyeti Araştırmaları Dergisi (SEMA) 5 (Aralık 2020), 77-96. https://doi.org/10.47702/sematr.2020.5

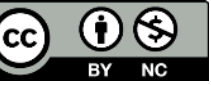

"This article is licensed under a Creative Commons Attribution-NonCommercial 4.0 International License (CC BY-NC 4.0)"

\footnotetext{
${ }^{1} \mathrm{Bu}$ çalışmada, Necmettin Erbakan Üniversitesi Sosyal Bilimler Enstitüsü Tarih Anabilim Dalında halen yürütülmekte olan Hülâgû'nun Hayatı ve Faaliyetleri adlı yüksek lisans tezinden elde edilen verilerden yararlanılmıştır.
} 


\section{GíRiș}

Devrin kaynakları bozkır halklarının savaş konusundaki üstünlükleri üzerinde birleşmektedirler. Şehirli unsurlara göre yıkıcı etkilerle dolu bir savaş, bozkırın göçebe halkları için neredeyse alışılagelmiş sıradan bir olay gibidir. Bozkır orduları, yerleşik toplumların ordularına nazaran daha düzenli ve disiplinlidir. Bozkır insanlarının orduları için hız ve sürekli hareket seferler ve savaşlar için çok mühimdi. Göçebe bozkır toplumlarında toplumun her kesiminden şahıslar asker olarak kabul edilebilmekle birlikte kadınlar bile orduların birer unsurudur. Nitekim bozkır ordusu halkın ordusu olup "er" kelimesi yalnızca erkek, adam ve koca manasına gelmeyip aynı zamanda asker, savaşçı, muharip, ordu anlamlarına da gelmektedir. ${ }^{2}$ Orta Çağ'ın şüphesiz en güçlü devletlerinden biri, başlarda küçük kabileler şekilde örgütlenmiş Moğol halkının büyük bir azim ve kararlılıkla tek bir çatı altında toplanıp birleştirildiği Moğol Hanlığı'ydı. Bilhassa Orta Asya'nın kaderini derinden etkilemekle beraber, Rusya, Avrupa, Küçük Asya ve Orta Doğu'nun siyasi, ekonomik, kültürel ve idari açıdan çehresini ziyadesiyle değiştiren bu devletin kurucusu Temuçin adında bir Moğol ${ }^{33}$ dur. 1206 yılında Cengiz Han unvanını almasını müteakip çok kısa sürede Kırgız, Merkit, Nayman vb. kabileleri idaresi altına almıştır. Moğolların böylesine hızlı genişlemesi doğrudan Cengiz Han'ın ve beraberindeki komutanların askeri becerilerinin eseridir. ${ }^{4}$

Cengiz oğulları arasında, ismi ve hayatı ile ilgili detaylara en az rastlanılan, dönemin başlıca kaynakları tarafından hayatından en az bahsedilen kişi Toluy'dur. Çocukluğu ve gençliği hakkında sınırlı bilgiler bulunan Toluy'un, Reşîüuddin'in rivayetleriyle siyasi hayatı ve son zamanları ile ilgili daha geniş bilgiler edinilebilmektedir. İran ve Çin'de kendinden yaklaşık otuz yıl sonra teşkil olan hanedanların atası Toluy, Cengiz Han'ın Kongirat aşiretinden ${ }^{5}$ Dey Seçe'nin kızı Börte Uçin ${ }^{6}$ adlı baş hatundan doğan dördüncü ve son oğludur. Meşhur tarihçi Reşîdüddin'e göre o, diğer dört kardeşiyle beraber imparatorluğun “külüglerinden ${ }^{7}$ ” biriydi ve doğrudan Cengiz Han'1n meşru varisidir. ${ }^{8}$ Cengiz Han'ın Börte'den doğan son oğlu olmasından dolayı Yeke Noyan (Büyük Noyan) unvanını da taşımıştır. $\mathrm{Bu}$ nedenle yaşadığı dönemde Moğol Hanlığı'nın başkumandanı görevini üstlendiği

\footnotetext{
${ }^{2}$ Mustafa Uyar, İhanlı (İran Moğolları) Devleti'nin Askerî Teşkilâtı (Ortaçă̆ Moğol Ordularında Gelenek ve Dönüşüm) (Ankara: Türk Tarih Kurumu, 2020), 1-3.

${ }^{3}$ Moğol kelimesinin anlamın ise kaynaklar genellikle Saf ve Temiz olarak ifade etmektedir. Cengiz Han'dan sonra bu kavram bütün Moğolları içinde barındıran etnik bir tabir haline gelmiş, böyle kullanılmaya başlanmıştır. Abdrasul İsakov, Kırgız-Moğol İlişkileri (IX.-XV. Yüzyıl) (Ankara: Ankara Üniversitesi Sosyal Bilimler Enstitüsü, Doktora Tezi, 2014), 131.

${ }^{4}$ Osman Gazi Özgüdenli, "Moğollar", Türkiye Diyanet Vakfı İslâm Ansiklopedisi (İstanbul: TDV Yayınları, 2005), 30/225-229; A. Konstantin d'Ohhson, Moğol Tarihi, Denizler Imparatoru Cengiz, çev. Bahadır Apaydın (İstanbul: Nesnel Yayınları, 2008), 37-41; Moğollar'in Gizli Tarihi I, çev. Ahmet Temir (Ankara: Türk Tarih Kurumu, 1986), 1-19.

${ }^{5}$ Başlarda sıradan bir Moğol kabilesiyken Cengiz soylularına eş olmaları sayesinde ün ve şöhret kazanmışlar, Yüan ve Altın Orda devletinin siyasetinde etkili olmuşlardır. Mesela Kubilay'ın eşi Çabi ve oğlu Cingim'in karısı Kökeçin Kongirat kabilesine mensuptur. Aynı şekilde Cuci'nin evlendiği iki prenses de bu kabileye mensuptur. Christopher P. Atwood, "Qonggirad", Encyclopedia of Mongolia and the Mongol Empire (New York: Fact On File, Inc., 2004), 456-457.

${ }^{6}$ Kongiratlardan Dey Seçe'nin kızı Börte Uçin 10 yaşında iken 9 yaşında olan Temuçin ile evlendirilmiştir. Atwood, "Börte Üjin", 46; Cüveynî onu güzelliğine bir iltifat olarak Moğolca güzel kadın manasına gelen Yesuncin lakabıyla anmaktadır. Ondan doğan çocukların, annelerinin itibarının yüksek olması nedeniyle aynı ölçüde itibarlı olduklarını zikretmektedir. Alaaddin Ata Melik Cüveynî, Tarih-i Cihan Güşa, çev. Mürsel Öztürk (Ankara: Türk Tarih Kurumu, 2013), 94.

${ }^{7}$ Kölüg ya da Külüg Moğol lisanında Güçlü ve hızlı bir at anlamına gelmektedir. Reşîdüddin bu ifadeyi onların (Cuci, Çağatay, Ögedey ve Toluy) Cengiz Han'ın önemli oğulları oldukları ve imparatorluğun geleceği oldukları için bu ifadeyi kullanmıştır. Ferdinand D. Lessing, Mongolian-English Dictionary (Berkeley and Los Angeles: University of California Press, 1960), 501.

${ }^{8}$ Reşîdüddin/Boyle, The Successors of Genghis Khan, trans. John Boyle (New York and London: Columbia University Press, 1971), 159.
} 
bilinmektedir. ${ }^{9}$ Reşîdüddin'e göre yaşadığı dönemde Cengiz Han, Toluy’u nökeri ${ }^{10}$ olarak görmüştür. Aynı yazar devamında; Cengiz Han, genel ya da özel tüm meselelerde Toluy'u danışman olarak kullanırd ${ }^{\prime 11}$ demektedir. İmparatorluk içindeki görevlerini ise; Yurt ${ }^{12}$, ordo, refah, maliye, irakhta ${ }^{13}$, emirler ve Cengiz Han'ın özel ordusu tümüyle ona bağlıydı"14 diyerek sıralamıştır. Bu durum Toluy'un imparatorluk içinde kilit bir role sahip olduğunu ortaya koymaktadır. Nitekim Cengiz Han ile ilgili herhangi bir husus doğrudan Toluy'un gözetiminden geçmiş, Cengiz Han'ın bir nevi özel danışmanı olarak görev yapmıştır. Bu çalışmada Toluy'un yaşamı boyunca katıldığı ve yürüttüğü savaşlara odaklanılarak hayatı kronolojik bir şekilde anlatılmış, Moğol Devleti'nin askeri başarılarındaki etkisi ortaya konulmaya çalışılmıştır.

\section{Cengiz Han Dönemi (1206-ö. 624/1227)}

\section{Kin Seferi (1211)}

Toluy'un katıldığı ilk sefer, 1211 sonbaharında 20’li yaşlarının başındayken Kinlere ${ }^{15}$ karşı yapılan harekât neticesinde gerçekleşmiştir. Toluy, Kin seferi boyunca Cengiz Han'ın yanında görev alarak babasıyla Şantu'yu ${ }^{16}$ aşmış ve devamında meydana gelen savaşta galip gelmişlerdir. Şantu'nun biraz ilerisinde yapılan bu muharebe, Toluy'un hangi görevde olduğu bilinmemekle birlikte kaynaklarda isminin geçtiği ilk muharebedir. Muharebenin ardından Toluy babasının riyasetinde Kinlerin "Batı Sarayı" olarak adlandırdıkları Tai-tong-fu şehrinin kuşatmasına katılmış ve Moğollar burayı kısa sürede ele geçirmişlerdir. Tai-tong-fu'nun düşmesi ile Pekin yolu Moğollara açılmıştır. Cengiz Han'ın seddi aştığı ve bölgede başarılı olduğu haberini alan Kitan ${ }^{17}$ lideri Yelu Liuge ${ }^{18}$ Moğollara katılmış, ona destek için Tunking'i kuşatmıştır. Cengiz Han, Liuge'nin Tunking'i ele geçirmesinin ardından yorgun atlarını ve askerlerini dinlendirmek için karargâh kurmuş ancak kısa süre sonra gelen bir haber dinlenme faslının gecikmesine neden olmuştur. Zira Kin başkentinde

${ }^{9}$ Cüveynî ona Uluğ Noyan demektedir. Cüveynî, Cihangüşa., 453; Yeke, Moğol lisanında büyük demektir. B. Y. Vladimirtsov, Moğollar'ın Iç̧timâ̂ Teşkilâtı, Moğol Göçebe Feodalizmi (Ankara: Türk Tarih Kurumu, 1995), 157; Gregory Abu'l-Ferec, Abu'l Ferec Tarihi C. II, çev. Ö. Rıza Doğrul (Ankara: Türk Tarih Kurumu, 1987), 478.

${ }^{10}$ Başlarda Cengiz Han'ın özel koruması ya da özel hizmetlisi olarak iş yapsalar bile daha sonraları kurumlaşmış ve anlamı genişleyerek Cengizli soyluları tarafından yönetim ve askeri işlerde görevlendirilmeye başlanmışlardır. Paul D. Buell, Historical Dictionary of the Mongol World Empire (Maryland and Oxford: The Scarecrow Press, 2003), 202; Atwood, "Nökör", 406.

${ }^{11}$ Reşîüüdin/Boyle, Successor, 163.

12 Ordo ya da Hordu ile aynı anlama gelmektedir. Kafesoğlu yurt kelimesinin vatan anlamına geldiğini ileri sürmüştür. İbrahim Kafesoğlu, Türk Milli Kültürü (İstanbul: Ötüken Yayınları, 1998), 227.

${ }^{13}$ Reşîdüddin'de rastladığımız bu kelimeyi başka bir yerde tespit edememekle beraber metin içindeki dipnotta J. A. Boyle bu kelimenin "Süvari” anlamına geldiğini ileri sürmüştür. Reşîdüddin/Boyle, Successor, 163.

${ }^{14}$ Reşîüüddin/Boyle, Successor, 163.

15 Asıl adları Curcalar olan göçebe Türk-Tatar kavmi Kinlerin anayurtları Kore'nin kuzey taraflarıydı. XII. yüzyılın başlarında Kitanlara ve Çin'e karşı etkili bir mücadele yürüterek aynı yüzyılın sonlarına doğru etkili bir güç haline gelerek Güney Çin ile Tataristan'da etkin olmuşlar ve Pekin'e yerleşmişlerdir. d'Ohsson, Denizler Imparatoru Cengiz, 66-68.

${ }^{16}$ Pekin'in 240 km. doğusunda bulunan kalabalık bir nüfusa sahip bölgedir. John W. Dardess, "From Mongol Empire to Yüan Dynasty: Changing Forms of Imperial Rule in Mongolia and Central Asia", The History of Mongolia Volume I The Pre-Chinggisid Era Chinggis Khan and the Mongol Empire, ed. David Sneath \& Christopher Kaplonski (Folkestone (UK): Global Oriental, 2010), 372.

${ }^{17}$ Güneydoğu'lu Xianbilerin Yuwen şubesine mensup olan Kitanlar, İç Moğolistan'ın doğu taraflarında yaşayan bir halktır. Kurdukları Liao Hanedanı 907-1125 yılları arasında Mançurya bölgesi, Moğolistan ve Kuzey Çin sınırlarını kapsamıştır. Atwood, "Kitans”, 315.

${ }^{18}$ Yelü Liuge 1212 'de Kinlerin kendileri üstündeki baskılarından ve Cengiz Han'ın da Çin'e saldırmasını firsat bilerek Mançurya'da isyan eden Kitanlı Cürcen hanedanından bir soyludur. Kısa sürede 100 bin asker toplayan Liuge, Cengiz Han'a sadakatını sunduktan sonra askerleriyle ona katılmıştır. Atwood, "Manchuria and the Mongol Empire", 341. 
yaşanan ihtilal neticesinde Cengiz Han bunu firsat olarak değerlendirmiş, orduyu hazırlayarak birkaç ayda Çin Seddi'ni aşmış ve Kin sarayına yaklaşmıştır. Ancak Kinler ihtilal sonrası olası bir saldırıya hazır olduklarından Moğollara başarılı bir mukavemet göstererek Cengiz Han'1 bölgeden hızla çekilmeye mecbur ettiler. ${ }^{19} \mathrm{O}$ esnada Moğolların beklemediği bir müttefik olarak Hialar, Kin imparatorluğuna kuzeyden saldırmaya başlamışlardır. Cengiz Han da bu saldırıya paralel şekilde eşlik ederek kuzeyden hücuma başlamış ve Tunggon geçidi yönünde ilerlemiştir. Geçit önlerinde meydana gelen büyük muharebede Cengiz Han, maiyetindeki orduyla Kin ve Hula'an-Delegen müşterek düşman ordusuna karşı savaşa başlamıştır. Savaşın ilerleyen safhalarında Cengiz Han'ın zorlanmaya başladığı anlaşılmaktadır. Nitekim o anlarda Toluy ve eniştesi Çigü ${ }^{20}$, yenilmek üzere olan Cengiz Han'a düşman ordusuna yan kanattan saldırarak yardım etmişler, Kinleri büyük bir bozguna uğratmışlardır. Ardından Kinlere karşı neredeyse bir toplu katliam başlamıştır. Moğolların aldıkları galibiyet sonucunda Kinlerin Altın Hanı'nın, ${ }^{21}$ "Merkez Şehir" anlamına gelen Chungtu'yu (Pekin) ${ }^{22}$ terk ederek Nankin'e ${ }^{23}$ çekilmek zorunda kaldığı görülmüştür. ${ }^{24}$ Moğol ordusunun neredeyse mağlup olacağı bir anda, stratejik bir saldırı ile Kinleri bozguna uğratan Toluy ve damat Çigü, Cengiz Han tarafından taltif edilmişlerdir. ${ }^{25}$

Kin seferini anlatırken Reşidüddin, Toluy için "Toluy Han, Harplerin büyük bir muzafferiydi ve hiçbir şehzade onun kadar fazla ülke fethedememiştir" demiştir. ${ }^{26}$ Yazar sefer boyunca Toluy'un faaliyetleri hakkında dikkat çekici bilgiler paylaşmıştır. Nitekim yazarın anlatımına göre Cengiz Han Kıtay ülkesine savaşa gitmiş ve nihayetinde genişçe bir kasaba olan Tayanfu önlerine varmıştır. Reşîdüddin, hiç kimsenin yaklaşmaya cesaret edemeyeceği kadar güçlü ve müstahkem bir yerleşim yeri olarak aktardığı Tayanfu'nun içinde sayılamayacak kadar nüfus barındırdığını zikretmiştir. ${ }^{27}$ Nitekim onun verdiği bilgilerin, Polo'nun Tayanfu hakkında anlattıklarıyla örtüştüğü görülmektedir. ${ }^{28}$ Tayanfu kuşatması Cengiz Han tarafından devam ettirildiği sırada Toluy ve Çigü şehir surlarına bizzat ordularıyla beraber tırmanmış burayı ele geçirmişlerdir. Toluy ve Çigü'nün gerçekleştirdiği bu operasyonun genel bir saldırıdan çok ince düşünülmüş bir hile olduğu anlaşılmaktadır. Toluy ve Çigü gibi iki önemli komutanın ve hanedan üyesinin operasyonun baş aktörü olarak saldırıda yer almaları, adı geçenlerin ordu içinde askerlere motive unsuru olduklarını açıkça göstermektedir. Eserinde devamla Reşîdüddin, Tayanfu'dan ilerleyen ordunun kısa bir süre sonra Joju ${ }^{29}$ kasabasını kuşattığını ve ele geçirdiğini de eklemiştir. ${ }^{30}$

${ }^{19}$ d'Ohhson, Denizler Imparatoru Cengiz, 69-72.

${ }^{20}$ Cengiz Han'ın eşi Börte Üçin'in ağabeyi Alçi Noyan'ın oğlu olan Çigü, Cengiz Han'ın kızı Temülen ile evlenmiştir. Ayrıca Kubilay'ın baş eşi Çabi de Çigü’nün kız kardeşiydi. Atwood, "Qonggirad”, 456-457.

${ }^{21}$ Tatarlar Kinlerin başındaki hükümdarlarına Altan (Altın) Han demektelerdi. Kin, Çince "altın" demektir. d'Ohhson, Denizler Imparatoru Cengiz, 65.

${ }^{22}$ Kuzey Şehir anlamına gelmektedir. Kinlerin Çin'i istila etmelerinden önceki adı Yen-Kin idi. Tatarlar buraya Hanbaluk demekteydiler. d'Ohsson, Denizler İmparatoru Cengiz, 70.

23 Şangay'a üç yüz km uzaklıkta ve Yangtze Nehri’nde konumlanan Nankin Şehri, kısaca Ning olarak adlandırılır. Günümüzde Doğu Çin'de ki Jiangsu Eyaletinin başkentidir. Nanjing (NJ), "The Foundations Laid in the Six Dynsties" (Erişim Tarihi:11.08.2020)

${ }^{24}$ Minhâc-1 Sirâc el-Cûzcânî, Tabakât-ı Nâsırî Moğol İstilasına Dair Kayıtlar, çev. Mustafa Uyar (İstanbul: Ötüken Yayınevi, 2016), 50-51.

${ }^{25}$ Gizli Tarihi, 172-173; d'Ohhson, Denizler Imparatoru Cengiz, 72-73.

${ }^{26}$ Reşîdüddin/Boyle, Successor, 164.

${ }^{27}$ Reşîdüddin/Boyle, Successor, 164.

${ }^{28}$ Joju kasabasından çıktıktan sonra at üzerinde yaklaşık on gün mesafe uzaklıktadır. Şarap, Bağ ve İpek Böcekçiliğiyle meşhur ve bölgenin merkezî noktasıdır. Marco Polo, Dünyanın Hikâye Edilişi, Harikalar Kitabl, çev. Işıı Ergüden - Z. Zühre İlkgelen (İstanbul: Ötüken Yayınevi, 2019), 232.

${ }^{29}$ Marco Polo, güzel bağ ve bahçelere, çok iyi işlenmiş tarlalara sahip güzel bir şehir olarak nitelendirdiği bu yerin halkının genel olarak ticaret ve zanaatla geçindiğini söylemiştir. Marco Polo, Harikalar Kitabı, 231.

${ }^{30}$ Reşîüddin/Boyle, Successor, 164. 
Moğolların 1211'de başlayıp 1215'li yıllara kadar süren Kin seferi sonucunda kazandıkları zaferler, bölge halkını Kinlerin kendi güvenliklerini sağlayamadıkları gerekçesiyle Moğol saflarına katılmaya ittiği görülmektedir. Moğollar kendilerine sığınan bölge halkından eli silah tutanları ordularında istihdam etmişler, kırk yedi süvari alayı teşkil eden bir ordu oluşturmuşlardır. Kuvvetler oğulları Çağatay, Ögedey ve Cuci'ye, kalanı ise Cengiz Han'ın kendi maiyetinde istihdam edilmiştir. Toluy, babasının hissesinden sorumlu olduğundan Cengiz Han'a düşen pay aynı zamanda kendisinin idaresine verilmiş oluyordu. Geri kalan kuvvetler ise ileri gelen emirler ve Noyanlar ${ }^{31}$ arasında paylaştırılmıştır. ${ }^{32}$

\section{Büyük Batt Seferi (1219) ve Horasan Görevi}

Kaynakların Kin seferinden 1219 Otrar hadisesine dek Toluy hakkında bilgi vermediklerini görülmektedir. Sonuçları açısından Bozkır halklarının ve İslam aleminin üzerinde büyük bir etki bırakan Otrar hadisesi Karakorum'da duyulmuş ve Cengiz Han aynı yıl büyük bir kurultay düzenlemiştir. Kurultay, olayın sorumlusu olarak nitelendirilen Harizmşahlara karşı büyük bir sefer kararı almıştır. Gizli Tarih'in zikrettiğine göre Cengiz Han'ın baş hatunu Börte Uçin, savaşın Moğollar aleyhine sonuçlanması ihtimaline karşı iktidar mücadelesi yaşanmaması adına Cengiz Han'a dört oğlundan birini veliaht tayin etmesini tavsiye etmiştir. ${ }^{33}$ Börte Uçin'in önerisi ile oğullarını huzura çağıran Cengiz Han, veliahtlık meselesini bütün aile bir aradayken müzakereye koymuştur. İlk olarak en büyük oğul Cuci'ye söz verilmiştir. Cengiz Han'ın büyük evlat olduğu için Cuci'ye sırayı vermesi, Çağatay'ın babasının bu hareketini hazmedemeyerek huzurdayken ağabeyi Cuci ile ağır hakaretlerle $^{34}$ dolu bir kavgaya tutuşmasına sebep olmuştur. ${ }^{35}$ Olayın başlaması ve gelişmesi hakkındaki detaylar bizim konumuz dışında kalmaktadır. Ancak bilinmesi gereken husus olaylı müzakereden Ögedey'in kârlı çıkarak veliaht ilan edilmiş olduğudur. Toluy ise toplantı esnasında kesin bir şekilde Ögedey'den yana rey kullanmıştır. Gizli Tarih'e göre söz sırası kendine geldiğinde Toluy şöyle demiştir:

\section{"Han babam tarafindan intihab edilen}

Ağabeyimin yanında kalarak,

Unuttuğunu hatırlatmak isterim,

Uyumuş ise uyandırmak isterim!

Ben onun can yoldaşı,

Al atı için kamçısı olmak isterim!

Verdiğim sözü geciktirmem,

Sıramdan hiçbir zaman çıkmam!

Uzun seferde yanında bulunurum,

\footnotetext{
${ }^{31}$ Genelde askeri bir terim olarak görünse de, Araplar ve Farslardaki "Emir" ünvanına eşittir, askeri ve sivil yetkileri vardır. David Sneath, The Headless State, Aristocratic Orders, Kinship Society, Misrepresentations of Nomadic Inner Asia (New York: Columbia University Press, 2007), 114.

${ }^{32}$ d'Ohhson, Denizler Imparatoru Cengiz, 73.

${ }^{33}$ Gizli Tarihi, 174-175.

${ }^{34}$ Çağatay tartışma esnasında onun boynuna yapışarak, Merkitlerde esaretteyken doğduğunu yani kısacası Cengiz Han'ın oğlu olmadığını söylemiştir. Gizli Tarihi, 175.

${ }^{35}$ Gizli Tarihi, 175-176.
} 


\section{Klsa seferde yaninda bulunurum!,36}

Veliaht seçimi hanlığın içinde bulunduğu olağanüstü şartlar bağlamında isabetli bir karar olarak görülmelidir. Çünkü o dönem Harizmşahlar Devleti'nin ${ }^{37}$ azımsanmayacak gücü ve Asya'nın batısının Moğollar için iyi bilinmeyen bir coğrafya olması Cengiz Han'ı olası her sonucu göz önünde bulundurmaya itmiş olmalıdır. Ancak veliaht ilanı sadece günün şartlarında isabetli bir karar olmuş, Ögedey Han'dan sonra gelen iktidarlar boyunca Cengiz oğullarının oluşturduğu dört ulus birbirlerine karşı çok farklı ittifaklar içine girmişlerdir. Sonuç olarak Cengiz oğulları birbirleriyle kanlı mücadelelere girerek ve Cengiz Han'dan kendilerine miras kalan bölgelerde kendilerine ait bağımsız devletler kurarak imparatorluğun dağılmasına neden olmuşlardır.

Sefer hazırlıklarının bittiği 1219 sonlarında bütün ordu üç koldan oluşmaktadır. Birinci ordu doğrudan Cengiz Han ve Başkomutan Toluy'a, ikinci ordu Cengiz Han'ın ortanca oğulları Ögedey ve Çağatay'a, Üçüncü ordu ise büyük oğlu Cuci uhdesine verilmiştir. Toplamda 150 bin kişiden oluşan bu ordu eşit parçalara bölünmüş oluyordu. ${ }^{38}$ Kin Seferi boyunca Başkomutanlık görevinin üzerinde olup olmadığı tespit edilemeyen Toluy, Cengiz Han'ın Harîzmşahlara karşı başlattı̆̆ 1219 seferi boyunca ordunun başkomutanlık görevini yürütmüştür.

Harold Lamb'ın, Hovart'tan aktardığına göre Moğol ordusu toplam 230 bin kişi etmektedir. Sir Henry Hovart, ordunun bölümleri ve sayıları ile ilgili şu bilgileri vermektedir:

"Han'ın muhafizlart: 1.000

Tulu'nun kumanda ettiği merkez: 101.000

Sağ kanat 47.000

Sol kanat 52.000

Diğer müfrezeler 29.000

Toplam 230.000,39

Asya'nın iç ve kuzey steplerinde o dönem mevcut nüfus sayısı göz önüne alındığında Cahen'in verdiği 150 bin rakamının daha makul olduğu düşünmekteyiz. Nitekim o günlerde Moğollar ellerinden geldiğince yabancı unsurları ordularının dışında tutmuşlar ve askeri yapıyı korumaya çalışmışlardır.

Karakorum'dan ilerleyen üç kol ordusu 1220 yılında Otrar'da buluşmuş, Cengiz Han, Otrar önlerindeyken oğullarına ve noyanlarına çeşitli görevler ihdas etmiştir. Buna göre Otrar'ı oğullarından Çağatay ve Ögedey kuşatırken büyük oğlu Cuci, Cend ${ }^{40}$ ve Barçınlığ Kend' ${ }^{41}$ kuşatma görevi almıştır.

36 Çağatay, Cuci konuşmak için söz aldığında hiddetlenerek onun Merkitlerden geldiğini söylemiştir. Bu söylediğiyle Cuci'nin Cengiz oğullarından olmadığını ileri sürmeye çalışmış ve kendisinden üstün olamayacağını ifade etmiştir. Cengiz Han bunun üzerine oğlu Cuci’yi savununca Çağatay, Ögedey'ın taht varisi olmasını istemiştir. Bu fikir Cengiz Han'ın aklına yatınca Cuci ve Toluy'a fikirlerini sormuş, olumlu yanıt alınca Ögedey’ı namzet ilan etmiştir. Gizli Tarihi, 174-181; Vladimirtsov bunun bir tür sadakat yemini olduğunu ileri sürmüştür. Vladimirtsov, Moğolların İçtimai Teşkilatı, 153.

371097 yılında Harîzm bölgesi Büyük Selçuklulara bağlı bir yer olarak Kutbüddin Muhammed'in emrine verilmişti. Kutbüddin Muhammed ölünce Atsız liderliğindeki Harîzmşahlar, iç isyanlarla uğraşan Sultan Sancar'a karşı istiklâlleri ilan ederek bağımsız olmuşlardır. Cüveynî, Cihan Güşa, 255-262.

${ }^{38}$ Leon Cahun, Asya Tarihine Giriş, Kökenlerden 1405 'e Türkler ve Moğollar, çev. S. İnan Kaya (İstanbul: Seç Yayın Dağıtım, 2006) 181.

${ }^{39}$ Harold Lamb, Moğollar'in Efendisi Cengiz Han (İstanbul: İlgi Kültür Sanat Yayınları, 2006), 191.

${ }^{40}$ Aral gölünün doğu tarafinda yer alan ve günümüzde mevcut olmayan Cend, Siriderya nehri üzerinde Kazakistan sınırları içinde yer almaktadır. Abdülkerim Özaydın, "Cend”, Türkiye Diyanet Vakfi İslâm Ansiklopedisi (İstanbul: TDV Yayınları, 1993), 7/359. 
Cengiz Han ve Toluy ise yanlarına ünlü kumandanlar Cebe $^{42}$ ve Sübedey $^{43}$ Noyanları alarak Mâverâünnehr'e doğru ilerleme planı yapmışlardır. ${ }^{44} \mathrm{Bu}$ ordunun ilk hedefi Buhara'yı muhasara etmekti. Otrar'dan ilerleyen ordu Buhara yakınlarındaki Zernûk ${ }^{45}$ kasabasına ulaşmış, hemen kuşatmıştır. Kuşatma sonrası Moğollar, karargâhtan kasabaya elçi göndererek Zernûk halkına teslim oldukları takdirde merhamet göstereceklerini haber vermişlerdir. Mukavemet gücü az Zernûk halkı teklifi mecburen kabul etmiş, Moğollara elçiler ve beraberinde pek çok hediyeler göndermişlerdir. Fakat Cengiz Han, Zernûk devlet adamlarının bizzat huzuruna çıkmamalarına sinirlenerek bu kasabayı yıktırmış ve kasabadaki askerliğe elverişli kişileri Buhara kuşatmasında kullanmak üzere orduda istihdam etmiştir. Zernûk'tan ilerleyen Moğollar 1220 yılının ilk aylarında Buhara önlerine gelmişler, şehri sıkı bir kuşatmayla ele geçirmişlerdir. Dönemin meşhur tarihçilerinden Abû'l-Farac ve Cüveynî’nin kayıtlarına göre Cengiz Han ve Toluy, atlarıla buradaki büyük camiye girmiş, şarap içerek kadın oynatmışlardır. Aynı yazarlara göre Toluy, camiye girdikten hemen sonra atından inerek minbere çıkmış, halka atlarının aç ve yorgun olduğunu bu nedenle doyurulmasını emretmiştir. ${ }^{46}$

Moğollar Buhara'dan çıkarken şehri önce talan etmiş sonra yakmışlardır. Kerpiç yapıların bir bölümü dışında çoğu yerin birkaç gün içinde hızla kül olduğu zannedilmektedir. Daha sonra şehrin önündeki sahrada kurulan mancınıklardan Buhara'ya taşlar atıldığ 1 aktarılmıştır. ${ }^{47}$ Yaklaşık bir buçuk asır sonra bölgeden geçen Orta Çağ'ın meşhur seyyahlarından İbn Battûta ${ }^{48}$, Buhara'ya geldiğinde bu yerin Mâverâünnehr'in merkezi olduğunu söylemiş, İslam dini için mühim şehirlerden birisi olduğundan bahsetmiştir. Ancak İbn Battûta devamında Cengiz Han ve Toluy'un yıktığı şehrin büyük bir kısmının viran halde olduğunu şehrin vaktiyle âlim yatağı iken artık Buhara'da tek bir âlimin kalmadığını ileri sürmüştür. ${ }^{49}$

Moğol ordusu Buhara şehrinde bir süre dinlendikten sonra Semerkant yönünde ilerlemeye başlamıştır. Önce Zernûk'ta yapıldığı gibi Semerkant kuşatması için de buranın halkından askerliğe yarar kişiler Moğol ordusunda istihdam edilmiştir. ${ }^{50}$ Ayrıca Buhara'nın düştüğü sıralarda devam eden

\footnotetext{
${ }^{41}$ Barşın-Kent adıyla da bilinen Siriderya nehrinin batı yakasında yer alan bu kent, Oğuzlar tarafından kurulmuş, Harîzmşahlar Devleti'nin önemli bir ileri karakolu olmuştur. Bekir Deniz, "İpek Yolu Üzerinde Bulunan Eski Türk Şehirleri”, Ipek Yolunda Türk Kültür Mirası, haz. Fahri Atasoy (Ankara: Türk Yurdu Yayınlar1, 2014), 391-393.

42 Cengiz Han’ın 1201 yılında Tayciutları yendiği savaşta onun atını vurarak öldüren askerlerden biriydi. Maharetlerinden etkilenen Cengiz Han onu affederek yanına almış ve süvarilerinin başkumandanlığ görevi ile dört köpek unvanlı komutanlarının arasına katmıştır. Atwood, "Jebe (Yeme)", 265.

${ }^{43}$ Cengiz Han'ın en iyi ve en korkunç kumandanı olarak Kuzey Çin'den İran'a, Rusya'dan Macaristan’a kadar nam salan Sübedey Bahadır, demircilik zanaatıyla meşgul olan Uriyanghan adlı bir kabileye mensuptu. Babası Kaban 1203'te 100 kişilik saray halkıyla Cengiz Han'a bağlanmıştır. 1248'deki ölümüne kadar zamanla Cengiz Han'ın gözüne girmiş ve Kubilay Noyan, Cebe ve Celme ile onun dört köpeği sıfatıyla onurlandırılmıştır. Atwood, "Sübe'etei Ba'atur", 520-521.

${ }^{44}$ Cüveynî, Cihangüşa, 131; Reşîdüddin/Boyle, Successor, 165; Abdulkadir Yuvalı, Illhanlılar Tarihi I. Kuruluş Devri (Kayseri: Erciyes Üniversitesi Yayınları, 1994), 19.

${ }^{45}$ XV. yüzyıllarda mevcut olduğu bilinen Zernûc (Zernûk/Zürnuk), bugünkü Kazakistan'ın güneyinde Kızılkum ilçesinin Mayakum köyünden kuzeye doğru beş km. uzaklıkta bulunmaktadır. Mehmet Faruk Bayraktar, "Zernûcî”, Türkiye Diyanet Vakfi İslâm Ansiklopedisi (İstanbul: TDV Yayınları, 2013), 44/294-295.

${ }^{46}$ Abu'l-Farac, Abu'l-Farac Tarihi, 505; Cüveynî, Cihan Güşa, 131-134; Cûzcânî 7 Şubat günü Buhara önüne geldiklerini ileri sürmüştür. Cûzcânî, Tabakât-1 Nâsırî, 56-57.

${ }^{47}$ Cüveynî, Cihan Güşa, 136.

48 A. Said Aykut, "İbn Battûta”, Türkiye Diyanet Vakfi İslâm Ansiklopedisi (İstanbul: TDV Yayınları, 1999), 19/361-368.

${ }^{49}$ İbn Battûta, İbn Battûta Seyahatnamesi, haz. Mümin Çevik (İstanbul: Bilge Kültür Sanat, 2015), 277.

${ }^{50}$ Cüveynî, Cihan Güşa, 136-137.
} 
Otrar kuşatması başarı ile nihayete ermiştir. ${ }^{51}$ Otrar’ı ele geçiren Cengiz oğullarının merkez ordusuna muhtemelen Cengiz Han ve Toluy Semerkant yolunda iken intisap ettikleri anlaşılmaktadır. ${ }^{52}$

Semerkant yolundaki merkez ordusu 1220 yılı baharında bu şehri çok hızlı bir şekilde ele geçirmiştir. ${ }^{53}$ Ordu bahar ile yaz aylarını Semerkant ${ }^{54}$ ile Nahşeb ${ }^{55}$ arasında geçirmiş, askerler dinlendikten sonra sonbahar aylarında ileri harekât için hazırlıklar bitirilmiştir. Merkez ordusunun hedefi bu aşamadan itibaren $\operatorname{Tirmiz}^{56}$, Belh ${ }^{57}$ ve Tâlekan ${ }^{58}$ şehirlerinin ele geçirilmesidir. Cengiz Han'ın Tirmiz'e ilerlemeden oğullarını huzuruna çă̆ırarak toplantı düzenlediği ve onlara yeni görevler verdiği görülmektedir. ${ }^{59}$ Buna göre Cuci, Çağatay ve Ögedey'in görevi Harîzmşahların merkezi Ürgenç'in ${ }^{60}$ ele geçirilmesi, çevresindeki bölgenin Moğol nüfuzu altına alınmasıdır. Ürgenç’e gidecek ordu yola çıktıktan kısa bir süre sonra Nahşeb kasabasına ulaşan Cengiz Han ve Toluy, buranın meşhur bahçelerinde bir süre vakit geçirmişler, sürüler ve atlar doyurulduktan sonra Tirmiz şehrine ilerlemişlerdir. Moğollar henüz Tirmiz şehrine varmadan teamüllerince elçi göndermişler, eğer direnmezlerse aman vereceklerini bildirmişledir. Ancak Tirmizlilerin gelen elçiyi dikkate almayarak şehri süratle savunmaya hazırladıkları görülmüştür. On bir gün ve gece devam eden ağır kuşatma sonrası Tirmiz ele geçirilmiş, halkı müthiş bir katliama tabi tutulmuştur. Öldürme ve yağmalama işleri sona erdiğinde Kongurt ve Şuman ${ }^{61}$ taraflarına giden Moğollar kışı burada geçirmişlerdir. ${ }^{62}$

Askerler dinlendikten sonra Cengiz Han ve Toluy, ileri harekâtlarına devam ederek Belh şehrine gelmişler ve burayı kuşatmışlardır. Moğol kuşatmasının ağırlığına dayanamayan Belh, kanlı bir şekilde zapt edilmiştir. Cengiz Han kuşatma devam ederken Kin seferinde üstün başarı gösteren oğlu Toluy'u Horasan bölgesine göndermeye karar vermiştir. Kendisi ise kalan ordu ile Tâlekan'a doğru ilerlemiştir. ${ }^{63}$

Toluy'a verilen görev Herat, Nîşâbur ve çevresinin ele geçirilmesi ve Horasan'ın tümünde Moğol nüfuzunun güçlendirilmesidir. Yanına Cengiz Han tarafından merkez ordusunun yalnızca onda

${ }^{51}$ Cûzcânî, Cüveynî’nin aksine Otrar şehrinin Buhara'dan önce zapt edildiğini, Cengiz Han’ın bizzat kuşatmaya eşlik ettiğini iddia etmiştir. Cûzcânî, Tabakât-1 Nâsırî, 55.

52 Cüveynî, Cihan Güşa, 144; Cûzcânî, Tabakât-ı Nâsırî, 57-58.

${ }^{53}$ Cüveynî, Cihan Güşa, 143-147; d'Ohhson, Denizler Imparatoru Cengiz, 113.

${ }^{54}$ Günümüzde Özbekistan sınırları içinde kalan Semerkant Zerefşân Nehri’nin güney kıyısında vadiye hâkim yüksek bir mevkidedir. Osman Aydınlı, "Semerkant", Türkiye Diyanet Vakfi İslâm Ansiklopedisi (İstanbul: TDV Yayınlar1, 2009), 36/484-486.

${ }^{55}$ Hudud'a göre Nesef'te denilen bu yer tarımla uğraşan içinden nehir geçen çok güzel ve zengin bir kent olarak tasvir edilir. Hudud/Minorsky, "The Regions of the World" A Persian Geography 372 A.H.- 982 A.D, trans. V. Minorsky (Cambridge (England): Cambridge University Press, 1982), 114.

56 Özbekistan'ın güneyinde Amuderya (Ceyhun) nehrinin sağ yakasında Afganistan sınırına çok yakın bir noktada bulunmaktadır. Abdullah Muhammedcanov, "Tirmiz", Türkiye Diyanet Vakfi İslâm Ansiklopedisi (İstanbul: TDV Yayınlar1, 2012), 41/200-202.

57 Amuderya'nın güneyindeki Dehâs ırmağı üzerinde ve Kûhibâbâ dağının eteğinde kurulmuştur. Günümüzde bu yer Afganistan'ın kuzeyinde kalmaktadır. Tahsin Yazıc1, “Belh”, Türkiye Diyanet Vakfi Íslâm Ansiklopedisi (İstanbul: TDV Yayınları, 1992), 5/410-411.

${ }^{58}$ Günümüzde Afganistan'ın kuzey doğusunda yer alan Talekan/Talukan Tirmiz'in güneyinde Cüzcan sınırında bir yerdir. Hududülalem'de çok güzel bir yer olarak tasvir edilen bu kent şarap ve keçe üretimiyle tanınmıştır. Hudud/Minorsky, 107.; İbn Hurdazbih'e göre buranın o günkü harac1 21400 dirhemdi. İbn Hurdazbih, Yollar ve Ülkeler Kitabı, çev. Murat Ağarı (İstanbul: Kitabevi Yayınları, 2008), 42.

${ }^{59}$ Cûzcânî, Tabakât-1 Nâsırî, 58.

60 Arapların Cürcaniye dedikleri Türkistan'ın kapısı konumunda olan Ürgenç/Gürgenç Amuderya'nın sol kıyısında yer alır. Harîzmşahlar Devleti'nin idari ve ekonomik başkenti olmuştur. Aydın Taneri, "Gürgenç", Türkiye Diyanet Vakfi İslâm Ansiklopedisi (İstanbul: TDV Yayınları, 1996), 14/321-323.

${ }^{61}$ Şuman bir dağ yamacına kurulmuş çevresi duvarla çevrili güçlü bir şehirdir merkezi dağın zirvesidir. Safran üretimiyle meşhurdu. Hudud/Minorsky, 115.

${ }^{62}$ Cüveynî, Cihan Güşa, 152.

${ }^{63}$ Cüveynî, Cihan Güşa, 152-154. 
biri verilmiştir. Belh'te askeri hazırlıklarını tamamlayan Toluy, orduyu sağ ve sol kol olarak tekrar düzenlemiş, başlarına çeşitli Noyanlar tayin etmiştir. Kendisi merkezdeki kuvvetin başına geçerek yola çıkmıştır. Toluy, ilk olarak bir keşif birliğini önden yollamış, ardından Mervcuk ${ }^{64}$ ve Bagşur ${ }^{65}$ yolundan geçmiştir. ${ }^{66}$ Muhtemelen bu zengin ve müreffeh kasabalarda bir süre dinlenerek ordusuna takviye sağlamıştır. Toluy'un karargâhına henüz buradayken üzücü bir haber geldiği görülmektedir. Olay şöyle gerçekleşmiştir: Belh'ten ayrılırken Toluy, Balkuş adlı bir adamını öncü kuvvetlerinin başına atayarak göndermiştir. Nese ${ }^{67}$ şehri önlerine gelen Komutan Balkuş, şehir surlarına yakın olduğu bir esnada buranın halkı tarafindan oklanarak öldürülmüştür. Muhtemelen Nese şehri Toluy’un hedefleri arasındadır ve Balkuş bölgeye inceleme ya da şehrin teslim alınması göreviyle gelmiş olmalıdır. Toluy'un ise bu esnada Merv işiyle ilgilenmek istediği düşünülmektedir. Komutanının ölümüne çok üzüldüğü anlaşılan Toluy, sevdiği askerlerden Balkuş’un öcünü almak için ordunun yönünü Nese'ye çevirmiştir. Hızla Nese önlerine gelen Moğol prensi, hazırlıklarını bitirmiş fazla beklenmeden şehri kuşatmıştır. Toplam 15 günlük kuşatma sonucunda şehir surlarında açılan gedikten Moğol askerleri içeri girmişler ve şehri süratle düşürmüşlerdir. Şehir yağmalanmadan önce halk1 buradan elleri bağlanarak sahraya çıkarılmıştır. Sahradan kimsenin kaçmaması için güvenlik tertipleri alındıktan sonra Moğol askerleri, Toluy emriyle yetmiş bin kişiyi öldürmüşlerdir. Toplu katliamın ardından Nese şehrinde nefes alan hiçbir canlı bırakılmamış, şehir üç gün boyunca yağmaya tabi tutulmuştur. Yağmanın ardından Toluy, Nese yakınlarındaki Harzenk Kalesi'ne yönelmiş kısa süreli bir kuşatmayla burayı da ele geçirmiştir. ${ }^{68}$

Bu başarılar otuz yaşlarında, üstün askerî becerilerle dolu, zeki ve genç prens için henüz bir başlangıcı ifade etmektedir. Nitekim henüz yirmili yaşlarında Çin seferinde gösterdiği başarılarından dolayı o, diğer üç ağabeyine nazaran askeri becerilerinin daha üstün olduğunu kanıtlamıştır. Ancak Toluy'un en büyük zafiyeti anlık öfkesidir. Hayatının, öfkeli karakterinin sonucu olarak verdiği müthiş şiddet içeren kararlar ile dolu olduğu anlaşılmaktır. Öldürme konusunda babası Cengiz Han'1 aratmamakta çoğu zaman onu dahi geçmektedir. Toluy, Horasan seferi boyunca Merv, Mervcuk, Serahs ${ }^{69}$, Herat ${ }^{70}$ ve Nîşâbur ${ }^{71}$ gibi büyük bir coğrafi alanı birçok kaynağın birleştiği üzere yaklaşık iki

\footnotetext{
${ }^{64}$ Hudud'a göre dağ eteklerine kurulmuş bol meyvelere sahip güzel ve zengin bir kasabadır. Belh’ten buraya büyük bir kervan yolu gitmektedir. Merv Nehri de kenarından akmaktadır. Hudud/Minorsky, 39, 105; İbn Hurdazbih'e göre ise haracı neredeyse 800.000 dirhemdir ki Hudud/Minorsky'daki bilgiler onu doğrular niteliktedir. Buranın yöneticilerine "keylan" denmiştir. İbn Hurdazbih, Yollar ve Ülkeler, 42, 45.

${ }^{65}$ Cüveynî’nin bahsettiği yer Bagşur olmalıdır. Nitekim Hududü’l-Alem de bahsetmektedir. Bozkır üzerinde kurulmuş bu küçük yerleşim birimi Mervcuk'tan bir dağ ile ayrılmaktadır. Su ihtiyacını kuyulardan sağlamaktadır. Vullers'a göre Bagşur, gav-i ab-i shur yani tuzlu su havuzu anlamına gelmektedir. Hudud/Minorsky, 104, 327.

${ }^{66}$ Cüveynî, Cihan Güşa, 164.

${ }^{67}$ Hududülalem'e göre kötü bir iklime sahip olan Nese dağ eteklerinde kurulmuş etrafı çöl ile çevrili çok güzel bir kasabadır ve kasabadan akarsu geçer. Hudud/Minorsky, 103.

${ }^{68}$ d'Ohhson, Denizler Imparatoru Cengiz, 117-118.

${ }^{69}$ Serahs, Horasan bölgesinin Güney Türkmenistan tarafında bulunan, tarımla geçimini sağlayan, içerisinden pek çok alim ve bilginin çıktığı tarihi bir şehirdir. Tecen Irmağı üzerinde kurulmuştur. Yüksel Sayan, "Serahs", Türkiye Diyanet Vakfi İslâm Ansiklopedisi (İstanbul: TDV Yayınları, 2009), 539-542.

${ }^{70}$ Afganistan'ın batısında yer alan Herîrûd Irmağının kenarında kurulmuş çok eski tarihi bir kenttir. Recep Uslu, "Herat", Türkiye Diyanet Vakfı İslâm Ansiklopedisi (İstanbul: TDV Yayınları, 1998), 17/215-218.

${ }^{71}$ Horasan'ın en önemli kentlerinden olan Nîşâbur, Binâlûd Dağı'nın güney batısında, denizden 1210 metre yükseklikte ve Tahran'ı Meşhed'e bağlayan yol üzerinde yer almaktadır. Osman Gazi Özgüdenli, "Nîşâbur", Türkiye Diyanet Vakfi İslâm Ansiklopedisi (İstanbul: TDV Yayınları, 2007), 33/149-151.
} 
üç ayda ele geçirmiş, Sîstan'i (Kûhistan) ${ }^{72}$ ve Çuhçeren'i de tahrip etmiştir. Bütün bu işler bittikten ve bölgede Moğol nüfuzu yayıldıktan sonra Tâlekan kuşatmasındaki babasının yanına geri dönmüştür. ${ }^{73}$

Merv Kuşatması: Toluy'un ilk büyük hedefinin İpek Yolu ${ }^{74}$ üzerinden geçmesi nedeniyle dönemin en stratejik şehirlerinden biri olan Merv olduğu görülmektedir. ${ }^{75}$ Henüz Toluy'un Nese'de olduğu sıralarda Merv'de birtakım olaylar gelişmektedir. Bölge ileri gelenlerinden Merv hâkimi Mücirülmülk, Tatarların bölgeye yaklaştıkları ilk günlerden beri izlemektedir. Ancak son zamanlarda bölgeden Tatarlar ile ilgili kendisine az haber gelmeye başlayınca onların burayla ilgilenmediklerini düşünerek şehirde aldığı önlemleri gevşetmeye başlamış, şehir ayânı ile eğlenceye dalmıştır. O dönem Amuye valisi olan İhtiyârüddin, Mücirülmülk'e gelerek Moğolların Kelat ve Nev kalelerini kuşatmakta olduğunu ayrıca bir kuvveti de kendi üzerine yani Amuye'ye yolladıklarını, bu nedenle kaçarak yanına geldiğini söylemiştir. Bunun üzerine Mücirülmülk, İhtiyarüddin'i şehirde bulunan Türkmen $^{76}$ askerlerin arasına komutan olarak atamıştır. Fakat bu karar Mücirülmülk aleyhinde bir durum oluşturmuş, Amuye valisi İhtiyarüddin Türkmenler ile anlaşarak şehrin yönetimini ele geçirmek istemiştir. İhtiyârüddin'in kendine karşı bir komplo içinde olduğunu önceden sezen Mücirülmülk, plan yaparak onu ve Türkmenleri şehirden kovmuştur. İktidarı ele geçirmek isteyen İhtiyârüddin ve Türkmenlerinin şehirden çıkarıldıktan sonra civardan ayrılmadıkları ve etraftaki köy ve kasabaları yağmaya koyuldukları görülmektedir. Merv'de bu taşkınlıklar sürmekteyken Toluy ordusuyla henüz Abıverd ve Serahs şehirlerini zapt etmiş, ileride yapmayı planladıkları savaşlarda kullanmak üzere orduya yeni askerler istihdam etmektedir. ${ }^{77}$

Cüveynî, Toluy'un o sıra yanında 70 bin kişilik bir kuvvet olduğunu söylemektedir ancak bu rakam mübalağalıdır. Toluy'un Merv yolunda iken yanında en fazla 15 bin askeri olmalıdır, nitekim Cengiz Han tarafindan kendisine ordunun onda biri tahsis edilmiştir. Sonunda Toluy'un bölgeye yaklaştığını belirten Cüveynî, öncelikle dört yüz kişilik bir öncü keşif grubunun çevreyi araştırma maksadıyla şehir civarına gönderildiğini zikretmektedir. Devamında ise bahsedilen öncü kuvvetlerin Merv önlerine geldiklerinde İhtiyârüddin ve himayesi altındaki Türkmen ordusuyla karşılaştıklarını aktarmaktadır. Ona göre öncüler, isyancılarla herhangi bir çatışmaya girmeden evvel gözlem yapmış ve gece olunca onlara sessiz bir şekilde tuzak kurmuşlardır. Cüveynî, yapılan plan sonucu Moğolların ani bir gece baskınıyla İhtiyârüddin ve Türkmenlerini imha ettiğini söyler. Müellif bunun için Moğolların süratle hareket ederek önce Türkmenlerin vurucu kuvvetini etkisiz hale getirdiklerini, koyun sürüsüne dalan kurtların yaptığı gibi çok az askerle asıl kalabalığın içine daldıklarını ve onları hızlıca bozguna uğrattıklarını kaydeder. Türkmenlerden kiminin yakınlardaki suda boğulduğunu kiminin ise Moğol k1lıcı altında öldüğünü ifade eden yazar, Moğolların imha işini bitirdikten sonra

\footnotetext{
${ }^{72}$ Bir kısmı İran'ın bir kısmı ise Afganistan'ın sınırları içinde yer alır. İsmi Farsça da "Sakaların Ülkesi” anlamına gelen Sakastân kelimesinden gelir. Osman Gazi Özgüdenli, "Sîstan”, Türkiye Diyanet Vakfi İslâm Ansiklopedisi (İstanbul: TDV Yayınlar1, 2009), 37/274-276.

${ }^{73}$ Reşîdüddin/Boyle, Successor, 165; Cüveynî, Cihan Güşa, 165; Gizli Tarih, 183.

${ }^{74} \mathrm{Bu}$ yolun ismi Alman coğrafyacı Ferdinand von Richthofen tarafından verilmiştir. Ana güzergâhı Çin'den başlayıp Orta Asya ve İran üzerinden Mezopotamya’ya kadar ulaşmaktadır. Bu ticaret yolunun genel ürünü İpek malzemesidir. Nebi Bozkurt, "İpek Yolu”, Türkiye Diyanet Vakfi İslâm Ansiklopedisi (İstanbul: TDV Yayınlar1, 2000), 22/369-370.

${ }^{75}$ Chris Peers, Genghis Khan and the Mongol War Machine (Barnsley (England): Pen \& Sword Military, 2015), 213.

${ }^{76}$ XI. yüzyıldan itibaren Müslüman Oğuzları, gayrimüslim Oğuzlardan ayırt etmek için ortaya çıkan genel isim olmuştur. Faruk Sümer, "Türkmenler”, Türkiye Diyanet Vakfi İslâm Ansiklopedisi (İstanbul: TDV Yayınları, 2012), 41/607-608.

${ }^{77}$ Cüveynî, Cihan Güşa, 169-170.
} 
Türkmenlerin altmış bin koyunluk sürüsünü ve ganimetlerini şehir civarındaki boş alanda topladıklarını anlatır. $^{78}$

Cüveynî'nin yorgunluk nedir bilmeyen, kapkaranlık bir gece ve dalgalı bir denize benzeterek yücelttiği Toluy, yine aynı yazarın ifadesiyle "korku veren, sayısı çöl kumlarının sayısından daha fazla olan ordusuyla",79 25 Şubat 1221 yılında Merv önlerinde belirmiş ve Merv'in Firuze Kapısı önünde otağını kurmuştur. ${ }^{80}$ Beş yüz süvarisiyle birlikte altı gün boyunca surları inceleyen Toluy, yedinci günün şafağında stratejik açıdan önemini tespit ettiği Dervaze-i Şehristan kapısında durarak saldırıya geçmiştir. Kapı önünde meydana gelen muharebede ve sonrasında şehir iyice köşeye kıstırılmış, dört bir yandan tutulmuştur. Olayların aleyhinde geliştiğini ve şehrin düşeceğini anlayan Mücirülmülk, teslim olmaktan başka çare bulamadığı için İmam Cemâleddin'i yanında birçok hediye, katırlarla yiyecek, içecek ve nadir emtiaları ve barış talebi ile Toluy'un huzuruna göndermiştir. Elçiyi huzuruna kabul eden genç prens ona şehrin durumu hakkında sorular sormuş, Merv'deki zenginlerin ve bilginlerin bir listesini istemiştir. Öncelikle listedeki iki yüz kişinin bütün malvarlığını kendine getirten Toluy, sonrasında Moğol ordusunu şehre sokmuştur. Bütün halk tıpkı Nese'de yapıldığı gibi şehirden çıkartılarak sahrada uzun bir süre tutulmuştur. Dört gün sonra Moğollar sahrada topladıkları halktan sanatkârlar, bazı kız ve erkek çocuklarından oluşan dört yüz kişiyi ayırdıktan sonra geriye kalan bütün halkı kadın, çocuk ve yaşlı demeden imha etmişlerdir. ${ }^{81}$

Toluy ardından Merv kale ve surlarını yıktırmış, şehirdeki pek çok cami, kütüphane ve medreseyi yaktırmıştır. ${ }^{82}$ Ayrıca Cüveynî burada İmam Hanefi'nin mezhebine uyularak ${ }^{83}$ yapılıış bir caminin de yakıldığını aktarmaktadır. Yazar caminin imhasının belki de geçmişte Sultan Tekiş’in ${ }^{84}$ veziri Şemseddin Me'sud Herevî’nin Şafî̀ mezhebine göre yaptırdığı caminin, Hanefî mezhebi takipçilerince yakılmasının intikamı olduğunu belirtmektedir. ${ }^{85}$ Merv meselesini yoluna koyan Toluy, idareyi Emir Ziyaeddin Ali’ye vermiş ve Barmas'1 da şahne ${ }^{86}$ olarak tayin etmiştir. ${ }^{87}$ Merv şehri bu

\footnotetext{
${ }^{78}$ Cüveynî, Cihan Güşa, 170.

${ }^{79}$ Cüveynî, Cihan Güşa, 171.

${ }^{80}$ Cüveynî, Cihan Güşa, 171.

${ }^{81}$ Cüveynî, Cihan Güşa, 171-172.

82 İbnu'l-Esîr, el-Kâmil fi 't-ta'rih, C. 12, çev. Abdülkadir Özaydın (İstanbul: Bahar Yayınları, 1991), $352-353$.

83 Hanefî, Şafîi, Malikî ve Hanbelî mezhepleri, yaygın oldukları bölgelerde şehircilik ve mimarîyi etkilemişlerdir. Örneğin Şafî̂ler camilerin tezyin edilmesini namaz kılanların dikkatini çekmesi nedeniyle mekruh olarak görmüşlerdir. Bununla birlikte Hanefî mezhebince cami tezyin etmek helal mal ile yapılmak kaydıyla serbest bırakılmıştır. İç ve dış süslemedeki mezhepler arasındaki bu farklılık yalnızca bu konuyla sınırlı kalmamış, Minber, abdest havuzu, cenaze mescidi, caminin genel planı vb. konularda da kendini göstermiştir. Yazarın kast etmeye çalıştığı husus bahsedilen fiziki husustur. Sümeyra Ocak - Aziz Doğanay, "İslam Mimarîsinde Mezhep Etkisi: Fas Câmileri Örneği”, İstem 33 (Haziran 2019), 89-109.

${ }^{84}$ İlarslan b. Atsız'ın oğlu olan Aleaddin Tekiş, 1172'den 1200'e kadar Harizmşahlar tahtında kalmıştır. Onun döneminde Harizmşahlar bölgenin en güçlü devleti olmuştur. Hanedanın en parlak hükümdarı sayılmaktaydı. Meryem Gürbüz, "Tekiş, Aleaddin”, Türkiye Diyanet Vakfi İslâm Ansiklopedisi (İstanbul: TDV Yayınları, 2011), 40/364-365.

${ }^{85}$ Cüveynî, Cihan Güşa, 172.

${ }^{86}$ Sözlükte “yük, azık, düşmanlık, at sürüsü” anlamlarına gelen kelimedir. Bir şehir ya da bölgenin emniyet ve asayişinden sorumlu askeri vali anlamına gelen Şahne, Samaniler, Selçuklular, Abbâsîler, Gazneliler kullanılmıştır. Erdoğan Merçil, "Şahne”, Türkiye Diyanet Vakfi İslâm Ansiklopedisi (İstanbul, TDV Yayınları, 2010), 38/292-293.

${ }^{87}$ Cüveynî, Cihan Güşa, 172.
} 
felaketten sonra Timurlu Şahruh ${ }^{88}$ zamanına kadar eski müreffeh zamanlarına dönememiştir. Şahruh kendi döneminde şehri tekrar eski haline döndürmek için büyük çaba sarf etmiştir. ${ }^{89}$

Nişâbûr Kuşatması: Merv, Toluy'un şehre getirdiği yıkım ile sarsıldığı sıralarda Nişâbûr halkının henüz bundan haberinin olmadığı açıkça görülmektedir. Şehir halkı Moğolların buraya kadar geleceğine ihtimal vermemektedir. Nitekim o sıralar Nişâbûr önemli bir misafiri, Harizmşah Sultanı Muhammed' ${ }^{90}$ ağırlamaktadır. Harizmşah Sultanı Muhammed, Nişâbûr'a kısa bir süre önce kaçtığı Belh şehrinden, 18 Nisan 1220'de gelmiştir. Cüveynî'nin anlatımına göre Muhammed, Nişabûrlulara Moğollara karşı konulamayacağı şeklinde umutsuz bir konuşma yaparak Moğolların bir gün Nişâbûr'a ve civarına da geleceklerini söylemiştir. ${ }^{91}$ Ancak Sultan Muhammed, Nişâbûr halkının kendi sözüne iltifat etmediğini ve şehirden ayrılmamakta kararlı olduklarını görünce işe koyulmuş, birtakım savunma önlemleri alarak burayı müstahkem bir hale getirmeye çalışmıştır. Sultanın yanına bir müddet sonra Belh savunmasıyla görevlendirmiş olduğu ancak Moğol komutanlarından Cebe ve Sübeday'ın kendi üzerine yürüdüğünü duyunca Belh'ten kaçan oğlu Celâleddin gelmiştir. Sultan, oğlunun takibata uğradığı haberini alınca acil olarak şehirden ayrılmıştır. Giderken arkasında Nişâbûr'u yönetmeleri ve savunmaları için Fahrülmülk, Nizameddin Abûlmealî Kâtib-i Camî, Ziyaülmülk Ariz-i Zuzenî ve Mucirülmülk Kafî Ömer Ruhî gibi kişileri bırakmıştır. ${ }^{92}$

24 Mayıs 1220'de Cebe, Sübedey Noyan ve Taysi gibi meşhur Moğol kumandanlarının önderliğindeki öncü kuvvetlerin Nişâbûr önlerine dayandığı görülmektedir. Yaklaşık 1000 kişilik grubun amacı sultanı takip etmek ve yakalamaktır. Kuvvetler, şehre yaklaşınca önce buraya adam göndermiş ve şehri itaate çağırmışlardır. Ancak Vali Mücirülmülk ancak sultanı yakalarlarsa itaat edeceğini bildirmiş ve bu şekilde şehrin idaresini elinde tutmaya, direnmeye çalışmıştır. Komutan Cebe şehri alma konusunda başarısız olunca Mücirülmülk’ten askerlerine dağıtmak üzere para istemekle yetinmiştir. Şimdilik Moğolları para ile savmayı başaran Nişâbûrlular her iki günde bir onlara para vermeye başlamıştır. Gelen bir istihbarat nedeniyle Moğollar bir süre sonra şehir ahalisine surları yıkmaları tavsiyesinde bulunarak oradan ayrılmış ve sultanın peşine düşmüşlerdir. Moğollar gittikten bir süre sonra şehre Moğolların sultan tarafından Irak'ta yenilgiye uğratıldı̆̆ı gibi asılsız haberler gelmiştir. Moğolların Tûs'ta ${ }^{93}$ bıraktığı şahne pek çok kez Şadyah'a haber gönderip dedikodulara inanılmaması, Moğolların herhangi bir yenilgiye uğramadıklarını ve itaatlerinde gösterecekleri bir zayıflığın Moğolları sinirlendireceği uyarısında bulunmuş olsa da Nişâbûr' dan sert üsluplu cevaplar almıştır. Bu haberlerin ardından Tûs askerlerinin başındaki Siraceddin adlı bir komutan, Tûs’taki Moğol şahnesini öldürüp başını Nişâbûr'a yollamıştır. Haber civarda adı bilinmeyen bir beldeyi idare eden vali tarafindan o esnada üç yüz atlısıyla Moğol sürülerine çobanlık yapmakta olan Kuş-Timur'a bildirilmiştir. Kuş-Timur, emri altındaki Noyanlara bilgi gönderdikten

\footnotetext{
${ }^{88}$ Timurlu devletini kuran Timur'un dördüncü oğlu olarak doğmuştur. Babasının ölümü üzerine 1405 'te tahta çıkmış, öldüğü 1447 yılına kadar hükmetmiştir. İsmail Aka, "Şâhruh", Türkiye Diyanet Vakfi İslâm Ansiklopedisi (İstanbul: TDV Yayınları, 2010), 38/293.

${ }^{89}$ İsmail Aka, "Mirza Şahruh Zamanında Timurlularda İmar Faaliyetleri”, Belleten 47 (Ocak-Nisan 1994), 189190.

${ }^{90}$ Şehzadeliği sırasında Horasan valiliği yapan Muhammed b. Tekiş, 1200 yılında Harizmşah tahtına çıkmıştır. 1220 yılında Moğolların ailesini esir ettiğini duyunca üzüntüsünden hastalanmış ve aynı yıl ölmüştür. Abdülkerim Özaydın, "Muhammed b. Tekiş", Türkiye Diyanet Vakfi İslâm Ansiklopedisi (İstanbul, TDV Yayınları, 2005), 30/581.

${ }^{91}$ Cüveynî, Cihan Güşa, 178-179.

92 d'Ohhson, Denizler İmparatoru Cengiz, 105-106; Cüveynî, Cihan Güşa, 178-180; Cûzcânî, Tabakât-ı Nâsırî, 58.

93 Müslümanlar tarafından ilk kez Hz. Osman devrinde ele geçirilen Tûs, günümüzde Horasan'ın Meşhed şehrinin $25 \mathrm{~km}$. batısında bulunur. Ortaçağ’da Firdevsî, Ebû Ca'fer et-Tûsî, Esedî-i Tûsî, Nizâmülmülk, Gazzâlî, Şerefeddin et-Tûsî, Nasîrüddîn-i Tûsî ve Alâeddin et-Tûsî gibi ünlü şahıslar buradan çıkmıştır. Rıza Kurtuluş, "Tûs”, Türkiye Diyanet Vakfi İslâm Ansiklopedisi (İstanbul: TDV Yayınları, 2012), 41/431-432.
} 
sonra süvarileriyle hızla Tûs'a giderek burayı yanına topladığı üç bin adamla ele geçiren Siraceddin'i ve isyancıları öldürmüş Tûs surlarını yıkmıştır. ${ }^{94}$

Bölgeden gelen haberler Cengiz Han'ın damadı Togaçar'a ulaşmıştır. Ekim ayında Togaçar, Toluy'un öncüsü olarak yanında çeşitli Moğol emirleri ve on bin kişilik bir kuvvet olduğu halde Nişâbûr önlerine gelmiştir. Nişâbûrlular şehri teslim etmeyerek direniş kararı almış ve sıkı bir savunma savaşı başlatmışlardır. Savaşın üçüncü gününde, Kara-kuş burcunda çarpışmalar şiddetlendiği esnada adı geçen burç önünde Nişâbûr halkı açısından vahim sonuçlar doğuran bir olay yaşanmıştır. Cengizli ailesinin mühim damatlarından Togaçar, şehirden gelen kör bir okla vurularak öldürülmüştür. Kaynaklardan Nişâbûrluların Togaçar'ı öldürdüklerinden dolayı çok sevindikleri, önemli bir iş yaptıklarını düşündükleri aktarılmaktadır. Bu sırada Moğol kuvvetleri Togaçar'ın ani ölümüyle geri çekilmiş, ordunun başına Togaçar yerine Börkay Noyan atanmıştır. ${ }^{95}$

Orduyu iki kısma ayıran Börkay, kendi kuvvetleriyle Sebzevar'a ${ }^{96}$ giderek önce burayı ele geçirmiştir. Diğer kuvveti ise Kuş-Timur'a destek olarak yollamış ve onun tekrar karışıklık içine düşen Tûs'ta egemen olmasını sağlamıştır. Toğaçar'ı sonra Moğolları bastırdıklarını ve onlara üstün geldiklerini düşünen Nişâbûrlular etrafta gezen sıradan ya da tacir Moğollara karşı dahi saldırmaya ve öldürmeye başlamışlardır. Börkay ve öncü kuvvetler kış geldiğinde Nişâbûr giriş ve çıkışlarını tuttuklarından dolayı Nişâbûr'da her türlü malın fiyatı büyük bir artış göstermiştir. Bu sırada bütün olup bitenlerden haberdar olan Toluy, 1221 başlarında Merv işini bitirerek doğrudan buraya hareket etmiştir. Merv ile Nişâbûr arasında geçtiği bütün yerleri zapt eden Toluy, buralardan askerliğe elverişli kişileri yanında istihdam ederek ilerlemiştir. Ayrıca yanında yaklaşık 3000 mancınık, kaynar zift atan 700 savaş aleti, 4000 merdiven, 2500 araba taş vardır. Civardaki dağlarda ise kullanılmaya müsait pek çok taş mevcuttur. Dolayısıyla Toluy ve yanındaki kuvvetlerin görüntüsü inanılmaz muazzam görünüyor olmalıdır. Zira şehir surlarından manzarayı izleyen halk o andan itibaren olayın ciddiyetini anlamış ve kadı-yı memalik ${ }^{97}$ Rükneddin Ali b. İbrahim Mugisî’yi elçi olarak Toluy’a yollamıştır. Mugisî halkın bağışlanmasını dileyerek genç prense para ve mal vaadinde bulunmuş ancak Toluy tarafından dikkate alınmayarak tutuklanmıştır. Toluy ilk olarak işe Nişâbûr etrafindaki bütün köy ve kasabaları tahrip ederek başlamıştır. ${ }^{98}$

7 Nisan 1221 Çarşamba günü başlayan Moğol hücumu cuma sabahına değin sürmüştür. Cuma günü Şuturbanân ve Karakuş kapısında savaş bir hayli şiddetlenmiş o sırada bir Moğol askeri Hüsrev Köşk surunun üzerine Moğol bayrağı çekmeyi başarabilmiştir. Moğollar hılı bir şekilde duvarlara tırmanarak Şuturbanân kapısından içeri girmişler, cumartesi akşamına dek surların üzerindeki her nokta Moğol askerleriyle dolmuştur. Şehrin her bir yanında yağma ve katliama başlanmıştır. Mücirülmülk işkenceden kurtulup çabucak öldürülebilmek için Toluy'a ağır sözler söylemiş ancak işkenceyle öldürülmekten kurtulamamıştır. Nişâbûr'a hâkim olan Moğollar halkı toplayarak şehrin dışındaki boş alana sürmüşlerdir. Toluy, kayınbiraderi Togaçar'ın intikamı için şehrin ziraat yapılacak hale sokulmasını, kedi ve köpekler de dahil olmak üzere şehirde nefes alan hiçbir canlı bırakılmamasını emretmiştir. Cüveynî’nin bilhassa "...şehrin ziraat yapılacak hale sokulması..."

\footnotetext{
${ }^{94}$ Cüveynî, Cihan Güşa, 180-181; Cûzcânî, Tabakât-1 Nâsırî, 58-59.

${ }^{95}$ Cüveynî, Cihan Güşa, 181.

${ }^{96}$ Yeşil tabiatı, madenleri ve değerli taşlarıyla bilinen, Horasan'ın önemli şehirlerinden Sebzevar'ın eski adıdır. İran'ın kuzeydoğusunda kalır. Enver Konukçu, "Beyhak”, Türkiye Diyanet Vakfi İslâm Ansiklopedisi (İstanbul: TDV Yayınlar1, 1992), 6/57-58.

97 Kadılar kadısı anlamına gelen "kad1-yı memalik" bir yer veya bölgedeki en üst düzey kadı olup bütün kadıların baş kadısı idi. İran bölgesinde bulunduğu şehrin kadısı ismiyle de anılmaktaydı. Örn. Nişâbûr Kadısı, Merv Kadısı gibi. Şükrü Özen, "Kâdılkudât", Türkiye Diyanet Vakfi İslâm Ansiklopedisi (İstanbul: TDV Yayınlar1, 2001), 24/77.

${ }^{98}$ Cüveynî, Cihan Güşa, 182.
} 
ifadesi ile anlatmaya çalıştığı husus şehrin tahrip edilip bütün binaların yıkılması anlamına gelmekte, kedi ve köpek gibi canlıların dahi hayatlarına kast edilmesi burada yapılan tahribatın Toluy'un diğer işleri göz önüne alındığında bir hayli büyük olduğunu göstermektedir. Zira Cûzcânî de, eniştesinin intikamını güttüğünü ileri sürdüğü Toluy’un buradaki faaliyeti hakkında “...ŞSehrin duvarlarını yıkıp, şehirdeki yapılardan hiçbir iz kalmaması için çift öküzü ile şehri sürdü."99 ifadesini kullanmıştır. Büyük tahribatın ardından Cengiz Han'ın kızı olan Togaçar'ın hanımı has ordusuyla Nişâbûra gelmiş, sahrada toplanmış 1000'lerce kişilik halkı katliama tabi tutmuştur. Olay sonrasında buradan yalnızca dört yüz kadar sanatkâr seçilerek Türkistan'a götürülmüştür. ${ }^{100}$

\section{Tangut Seferi ve Cengiz Han'ın Ölümü}

Toluy büyük bir hızla, yaklaşık üç ayda tüm Horasan bölgesini ele geçirmiş ve Moğollara bağlamıştır. Kendine verilen görevleri tam olarak yerine getiren Toluy, Cengiz Han'ın yanına dönmesi emriyle merkez ordusuna katılmak için Talekan yolunu tutmuştur. ${ }^{101}$ Bu noktada Cûzcânî, Nişâbûr sonrası ile alakalı diğer kaynakların bahsetmediği ilginç bilgiler paylaşmaktadır. Müellif, Toluy’un Nişâbûr'dan sonra Herat'a geldiğini, şehri 8 ay gibi bir müddette zapt ettiğini ve buraya bir şahne atadığını iddia etmekte, ondan sonra geriye döndüğünü ileri sürmektedir. ${ }^{102}$ Toluy'un dönüşü sırasında babası o sırada Talekan'da zorlu bir mücadele vermekte ancak burayı bir türlü ele geçirememektedir. Toluy muhtemelen bu yüzden çağırılmış olmalıdır. Zira dönemin yazarları Toluy'un gelişinden sonra Cengiz Han'ın ordusunun gücünün arttığını ve Cengiz Han'ın oğlu sayesinde Talekan'ın düşürüldüğünü ifade etmektedirler. ${ }^{103}$

Cengiz Han ve Toluy cephesinde olaylar bu şekilde cereyan ederken 1220 sonlarında Ürgenç'e gönderilen Ögedey ve Çağatay buradaki görevlerini bitirip babalarının yanına dönmüşler, Cuci ise aldığ 1 yeni emirle geride kalmıştır. Kardeşler arasında bölgede birtakım sorunlar meydana gelmiştir. Öyle ki Ürgenç'e geldikten sonra burada Çağatay ve Cuci bizim tespit edemediğimiz bir anlaşmazlık yaşamışlar ve babalarına bu hususta ne yapmaları gerektiğini sormuşlardır. Babaları ise bunun üzerine iki kardeşin veliaht prens Ögedey'a göre hareket etmelerini onun emirlerine uymalarını emretmiştir. Nisan 1221 'de Ürgenç'i ele geçiren Ögedey ve Çağatay, ordularıyla beraber Talekan kuşatmasındaki Cengiz Han ve Toluy'un yanına katıldılar. ${ }^{104}$ Karargâhta Moğol Hanı, Çağatay ve Ögedey'a hiç iltifat etmemiş ve huzuruna almamıştır. Nedeni ise üç evladın Harizm'de ele geçirdiği toprakları paylaşırken yaşadıkları anlaşmazlık sırasında babalarının hissesine düşen payı vermeyi unutmalarıdır. Moğolların Gizli Tarihi'ne yansıyan bu durum sonucunda Cengiz Han'ın onlara karşı itimadının az hatta sönmek üzere olduğunu anlamaktayız. Nitekim aralarında veliaht prensin de bulunduğu üç büyük evladın, Cengiz oğulları olarak yasayı daha çok sahiplenmeleri ve uymaları gerekirken Cengiz Yasalarını çiğnedikleri ve toprak paylaşımını uygun olmayan bir biçimde yaptıklarından dolayı bu muameleyi görmüş oldukları düşünmekteyiz. Neyse ki evlatların arabulucu olarak tuttukları üç önemli Noyan: Honghai-horçi, Hongtahar-horçi ve Şormahan-horçi, Cengiz Han ile oğulların arasını düzeltmiş ve onların affedilmelerini sağlamışlardır. ${ }^{105}$

\footnotetext{
${ }^{99}$ Cûzcânî, Tabakât-1 Nâsırî, 72.

${ }^{100}$ Cüveynî, Cihan Güşa, 183.

101 d'Ohhson, Denizler Imparatoru Cengiz, 123.

${ }^{102}$ Cûzcânî, Tabakât-1 Nâsırî, 72-73.

${ }^{103}$ Cüveynî, Cihan Güşa, 154.

${ }^{104}$ Gizli Tarih, 183; Cüveynî, Cihan Güşa, 145-151.

105 Gizli Tarih, 183-184.
} 
1221 y1lı sonbaharı ile Cengiz Han fetihlere devam etmeyi planlamaktadır. Ancak onun kafasını ayrıca o sıralar Gazne'de ${ }^{106}$ olduğu bilinen Sultan Celâleddin' ${ }^{107}$ yakalamak ve Harizmşah tehlikesine bir an önce son vermek meşgul etmektedir. Cengiz Han, Celâleddin'in peşinden Hindikuş Dağlarını ${ }^{108}$ aştıktan sonra Bamyan ${ }^{109}$ kasabasını kuşatmış ve zorlu bir mücadele ile burayı ele geçirmiştir. Moğol Hanı, Hindistan ve Sind'de ${ }^{110}$ Celaleddin'in yakalanması arzusuyla her yeri dolaşmış geçtiği her noktada büyük katliamlar yapmış ancak istediğine ulaşamamıştır. Doğudaki gelişmeler ise onu Hindistan'dan çekilmeye mecbur bırakmıştır. Nitekim hâlâ sindirilememiş Tangutlar ${ }^{11}$ isyan halinde olup bu mesele Celâleddin'in yakalanamaması ile daha önemli hale gelmiştir. Cengiz Han $1224^{\prime}$ te Ordasına ${ }^{112}$ dönerek hazırlıklara başlamış ${ }^{113}$ ancak 18 Ağustos h. 627/m. 1227'de Tangut ülkesinde seferdeyken Domuz y1lında ölmüştür. ${ }^{114}$

\section{Ögedey Han Zamanı (1229-ö. 629/1232)}

Toluy'un yaşantısı Ögedey Han'ın tahta çıkışı sonrasında da Cengiz Han döneminden farklı geçmemiş, yine hanın danışmanlığı görevini yürütmeye devam etmiştir. Nitekim Toluy'un yaptı̆̆ bu iş Ögedey Han için önemlidir. Çünkü Toluy, Cengiz Han ile katıldığı ya da tek başına idare ettiği savaşlarda büyük tecrübeler kazanmış ve büyük başarılar yakalamıştır. Dahası Moğol askerlerinin Toluy'a askerlik konusundaki becerisi nedeniyle büyük bir sevgi ve saygı taşıdıkları gözden kaçırılmaması gereken bir husustur. Ögedey Han bu sebeple Toluy ölene dek Cengiz Han'ın yaptığı gibi onu yanından ayırmamış, başta askeri meseleler olmak üzere pek çok işte ona danışarak görüşlerini almış ve uygulamıştır. Kurultay ile han ilan edilen Ögedey Han, aynı kurultaydan üç büyük sefer çıkartmıştır. Bunlardan ilki Çormagon Noyan emrinde İran'a sefer düzenlenmesi diğeri ise Göktay ve Sübedey emrinde Deşt-i Kıpçak bölgesine sefer düzenlemesidir. Üçüncüsü ise Ögedey Han'ın kendi yöneteceği Kin seferiydi. Aynı yıl Toluy ve diğer kuzenleriyle birlikte sefer hazırlıklarına başlamıştır. ${ }^{115}$

\footnotetext{
${ }^{106}$ En parlak devirlerini Gazneliler döneminde yaşayan şehir, adı geçen devletin yıkılmasından sonra Selçuklu nüfuzuna girmiştir. Afganistan'ın Kâbil şehrinin $145 \mathrm{~km}$. güneybatısında yer almaktadır. Enver Konukçu, “Gazne”, Türkiye Diyanet Vakfi İslâm Ansiklopedisi (İstanbul: TDV Yayınları, 1996), 13/479-480.

${ }^{107}$ Hârizmşahlar Devleti'nin son hükümdarı Celâleddin Hârizmşah, Moğolların Müslüman batı üzerine başlattığı seferin ortasında hükümdar olarak tahta çıkmıştır. Uzun bir süre boyunca Moğollara direnerek İran'a oradan Hindistan'a gitmiş Cengiz Han'ı dahi cengâverliği ile kendine hayran bırakmıştır. Aydın Taneri, "Celâleddin Hârzimşah", Türkiye Diyanet Vakfı İslâm Ansiklopedisi (İstanbul: TDV Yayınları, 1993), 7/248-250.

108800 km. boyunca Pakistan'ın kuzeyini çevreleyen yüksekliği ortalama 6000-7500 metre arası değişen dağ sırası. Encyclopedia Britannica (Britannica), "Hindu Kush”, (Erişim Tarihi: 02.05.2020).

${ }^{109}$ Güzgan ile Horasan bölgesinin sınırı üzerinde tarımla geçimini sağlayan bir yerleşim yeridir. Yöneticilerine Şîr denmekteydi. Hudud/Minorsky, 109;

${ }^{110}$ Pakistan'ın Güneydoğu tarafında İndus Nehri çevresinde uzanan tarihi bir bölgedir. Azmi Özcan, "Sind”, Türkiye Diyanet Vakfı İslâm Ansiklopedisi (İstanbul: TDV Yayınları, 2009), 37/242.

${ }^{111}$ Kuzey Batı Çin'de 1038'den 1227'ye kadar hüküm süren Tangutlar, 1205 ve 1209 yılında Cengiz Han'ın sistematik seferlerine maruz kalmışlardır. Kinlere karşı kısa süreli müttefiklikten sonra tekrar Moğollar ile araları bozulmuştur. Cengiz Han'ın ölümünden sonra Halkı ve Soyluları Moğollar tarafından katliama uğratılarak yok edilmişlerdir. Atwood, "Xia Dynasty", 590-591.

112 Hordu, Hordo ve Orda da denen bu kavram Moğol soylu ve aristokratlarının özel çadırdan sarayı anlamına gelmektedir. Soylular için ordolar, çekirdek güçlerinin bulunduğu yerdi. Bütün yönetimin merkezi burasıydı. Atwood, "Ordo", 426; Buell, Mongol World, 207.

113 d'Ohsson, Denizler İmparatoru Cengiz, 132; Cüveynî, Cihan Güşa, 147-165; Reşîdüddin/Boyle, Successor, 165; Yuvalı, Ilhanlılar, 24.

${ }^{114}$ Gizli Tarih, 190; Bertold Spuler, İran Moğollar'ı Siyaset, İdare ve Kültür İlhanlılar Devri (1220-1350), çev. Cemal Köprülü (Ankara: Türk Tarih Kurumu, 1957), 42; Abû'l-Ferec havanın kötü rutubetinden ileri gelen bir hastalığa yakalandığını ileri sürmüştür. Abû'l-Farac, Abu'l-Farac Tarihi, 522-523.

115 d'Ohhson, Denizler Imparatoru Cengiz, 165.
} 
1230 y1lında hazırlıklarını tamamlayan Moğol ordusu hareket etmiştir. Plana göre Ögedey Han tek başına Honan eyaletine ilerlemiş, kardeşi Toluy'a ise Kin başkentinin kuzeyinde kalan Şansi'yi fethetme görevi vermiştir. Toluy, Şan-si ile bölgenin merkezi olan Funsian şehrini hızlıca ele geçirmiştir. Ancak Ögedey Han, Honan eyaletini ele geçirmek istemiştir. Kuzeyden Sarı Çay batıdan yüksek dağlar ve Tunkuan kalesi ile çevrili Honan eyaletinin ele geçirilmesi için Toluy, ağabeyi Ögedey Han'a geçmişte babasının uygulamak isteyip uygulayamadığı planı önermiştir. Ögedey Han, Toluy'u planının uygulanması için yetkilendirmiş, harekete geçen Toluy, 30 bin süvari ile Şan-si'den çıkarak Sungların ${ }^{116}$ ülkesinin sınırına gelmiştir. Toluy, Siçuan isimli bu sınırdan askerini geçirmek için Sunglar ile anlaşarak izin almış ve onlardan rehberler temin etmiştir. Yüksek dağlardan aşağıya doğru zorlu bir inişin ardından Toluy ve ordusu, Honan eyaletinin sınırındaki Han ırmağına ulaşmıştır. Moğolları Han ırmağını henüz geçmeden, kıyıya yakın bir noktada olsa gerek, bölgeye düşman geleceği istihbaratını alan iyi teçhiz edilmiş Kin ordusu beklemektedir. Tun-hu civarında karaya çıkan Moğollar, Kin ordusuna ilk hücumu yaparak savaşı başlatmış, ancak Toluy istediği başarıyı elde edemeyerek geri çekilmiştir. Moğollar devam eden günlerde ani baskınlar ve vur-kaç taktikleri ile düşmandan epey mal kaçırmışlardır. Siçuan'dan Tunhu'ya süren uzun yolculukta ordusu yorgun düşen ve erzakı azalan Toluy, Tunhu'dan geri çekilerek düşman ordusuna bir süre görünmemiş̧tir. Toluy’un aldığ 1 bu yenilgi günümüzde Kai-fong-fu olarak adlandırılan Nankin'de büyük bir sevinç yaratmıştır. Kin hükümeti Şehir halkına Moğolların kaçışı sebebiyle şenlikler düzenleme izni vermiştir. Bundan sonra hükümet Nankin'e sığınan bölge halkını Moğolların çekildiğine inandırarak yurtlarına göndermiştir. ${ }^{117}$

Kin seferi Ögedey Han'ın istediği şekilde ilerlemeyince Moğollar yeni bir plan hazırlayarak tekrar harekât düzenine geçmişlerdir. Toluy, Tsinsu bölgesine doğru yürümekte, Ögedey Han Sarı Çay'a gelmek üzere, amcası Otçigin ise Şantung'a giden yol üzerinde ilerlemektedir. Nankin yönetimi Moğolların geri çekilmediklerini öğrendiğinde birtakım ani kararlar almaya çalışmış, bunda başarılı olamamıştır. Çünkü Ögedey Han kumandasındaki Moğollar Sarı Çay’1 çoktan geçmişlerdir. Sarı Çay’1 geçen Ögedey Han ve ordusu, Nankin'e yakın bir şehir olan Çinço'da karargâh kurmuştur. Nitekim bu esnada Tsinsu üzerindeki Toluy, kendini çekilmeye mecbur eden Kin ordusunu takip etmektedir. Kin ordusu ise bu sefer Sarı Çay’ı aşan Ögedey Han tehlikesi yüzünden Nankin'e şehri savunma amacıyla geri dönmektedir. Başarıyla onları izleyerek Nançu'ya kadar gelen Toluy, kısa bir süre sonra Ögedey Han ile birleşmiş ve Kin ordusunu kıstırmıştır. Moğol ve Kin ordularının aralarında çıkan büyük savaşta Kinler büyük bir bozguna uğramışlardır. Ardından Toluy hızlıca yakınlardaki Kionço'yu kuşatmıştır. Şehrin çevresine hendekler kazdıran Toluy, bu hareketi şehirden kimsenin kaçmaması için yapmıştır. Nihayet şehri ele geçirdiğinde buranın komutanı Onyenhota'nın idamına karar vermiş ve muhtemelen Kionço halkını da katletmiştir. Toluy, ağabeyi Ögedey Han ile bir araya geldiklerinde onunla hasret gidermiş ve ona Funsian'dan beri yaşadıklarını anlatmıştır. Nitekim onun ekseriyeti süvariden teşkil olan ordusu adı geçen Funsian dağlarında büyük zorluklar çekmiş olmalıdır. Bunları anlatan Toluy, ordunun buralarda çok sorun yaşadığını erzak yetersizliğinden dolayı günlerce ot yiyerek hayatta kaldığından bahsetmiştir. Zorlu günler geçirdiği ve ayakta kaldığı için abisinin ilgisini ve tebriklerini alan Toluy, Ögedey Han'a asıl teşekkür edilmesi gerekenin Moğol ordusu olduğunu söyleyerek mütevazi sayılabilecek bir cevap vermiştir. Ögedey Han ve Toluy, bundan sonra Tataristan'a dönmeye karar verdiler. Bu nedenle Kin imparatoruna barış teklif etmişlerdir. Ancak Kin hükümetiyle yürüttükleri müzakereleri bir anda durdurmuşlardır. Görülmektedir ki görüşmeler bölgedeki etkili bir siyasi gücün, Sungların devreye girmesiyle yarıda kesilmiştir. Sung diplomatları

\footnotetext{
116 960-1279 yılları arasında etkili olan bu hanedan Tang hanedanının yıkılmasıyla ortaya çıkan birçok vali kökenli devletçiklerden biriydi. Zamanla güçlenen Sunglar ilk olarak Kitanlara daha sonra ise Tangutlara kendilerini tanıtarak bölgede etkili bir siyasi güç olmuşlardır. Atwood, "Sung Dynasty (Sung)", 509.

117 d'Ohhson, Denizler Imparatoru Cengiz, 166.
} 
Ögedey Han'a Kinlerin yıkılması durumunda Honan Eyaletini vermeyi taahhüt etmişlerdir. Sunglar ile görüşüldüğü esnada Kin başkenti Nankin zaten Moğollar tarafından kuşatılmaktaydı. Teklif cazip gelince buna devam edildi. Kısa süre sonra şehir Moğollarca ele geçirildi ve büyük bir yağmaya tabi tutuldu. Böylece Cengiz Han'ın intikamı alınarak Kin imparatorluğu tarih sahnesinden silindi. ${ }^{118}$

1232 y1lında Ögedey Han ve Toluy, aralarında müzakere ettikten sonra geri dönmeye karar vermişlerdir. Çin seddini Koupe Kean geçidinden aşan iki kardeş yoldayken Ögedey Han çaresi bilinmeyen bir hastalığa tutulmuştur. Toluy, Ögedey Han'ın rahatsızlığı boyunca onunla fedakâr bir şekilde ilgilenmiştir. Nihayetinde çare için şamanlara başvurulduğunda onların reçetesi hanedan ailesinden bir kişinin şamanlar tarafından hazırlanan sihirli sudan içmesi olmuştur. $O$ an Ögedey Han'ın yakınlarında olan Toluy içinde sihirli su olan ağaç tası alıp tanrıya dua ederek kardeşinin yerine kendisini almasını dilemiş ve bu suyu içmiştir. Toluy'un suyu içmesinden kısa bir süre sonra Ögedey Han iyileşmiştir. Ordu tekrar hazırlanıp yola çıkmış, Tula ve Onon ırmaklarının ayrımı olan yere gelindiğinde bu sefer Toluy amansız bir hastalığa tutulmuştur. Ekim ayı civarında öldüğü düşünülen Toluy’un ölüm sebebinin içki ile çok hemhal olmasından ileri geldiği düşünülmektedir. Onun ölümünden Ögedey Han çok muzdarip olmuş iktidarı boyunca yıllarca kardeşini üzüntüyle anmıştır. ${ }^{119}$

Ölümü ile ilgili yukarıda verilen ilginç hikâyeyi Moğolların Gizli Tarihi aktarmıştır. Detaylara göre Ögedey Han'ın yolda dili tutulmuş ve hastalanmıştır. Şamanlar onun düşman büyücüler tarafından hasta edildiğine, büyü yapıldığına inanmışlardır. Han'ın hastalığı gittikçe ağırlaşırken Moğol şamanları hanedan soyundan birine ihtiyaç olduğunu söylemişlerdir. Ögedey Han etrafındaki prensleri sorduğunda o esnada Toluy da orada bulunmaktadır. Kahinlere ne yapmasi gerektiğini soran Toluy, onların hazırladığı efsunlu suyu içmiştir. Biraz sonra Toluy'un uykusu gelmiş ve Ögedey Han'a, karısına ve çocuklarına sahip çıkmasını vasiyet ederek ölmüştür. ${ }^{120}$ Moğollarda acemi tedavinin yanı sıra hastalığın dua ve dileme ile de bir kişiden başka bir kişiye geçtiği düşüncesi yaygındır. Bu olayda Ögedey Han ağır bir şekilde hastalandığında ona sıkı sıkıya bağlı olan Toluy, duada bulunmuş ve bu hastalık kendisine geçmiştir. Toluy'un ölümünün bu şekilde oluştuğu düşüncesi, muhtemelen Moğol halkına böyle anlatılmış, Moğollar'ın Gizli Tarihi adlı esere bu şekilde yansımıştır. ${ }^{121}$

\section{SONUÇ}

Kin seferi ile başlayan ve ölümüne dek süren askeri yaşamı boyunca Toluy, devletin ilk kurulduğu günden bu yana kritik görevler almıştır. Toluy, aldığı görevleri başarmada gösterdiği azim ve şahsen aldığı inisiyatifler sayesinde Moğol Devleti'nin büyüyüp güçlenmesinde ve dünya hâkimi bir devlet sıfatı kazanmasında en önemli Moğol şahsiyetler arasında yerini almıştır.

Toluy, Reşîüüdin'in Camî'u’t-Tevârîh adlı eserinde 1211 tarihli Kin Seferi hakkında anlattıkları düşünüldüğünde atılgan, hızlı karar verip uygulama yeteneklerine sahip, inisiyatif alarak hayatını tehlikeye atmaktan korkmayan, askerlik ile ilgili niteliklerin birçoğunu üzerinde toplamış cesur bir komutandır. Askerlik hayatının başlarında Kin seferi ve özellikle buradaki Joju Kasabası kuşatmasında üstlendiği tehlikeli görev, ardından Cengiz Han tarafından ödüllendirilmesi hususu bunun kanıtıdır. Kaynaklar özellikle Cengiz Han devri Moğol seferlerini anlatırken diğer kardeşlere nazaran Toluy'u daha çok anmaktadır. Toluy, imparatorluğun en önemli adamlarından biridir. Ayrıca Büyük Batı Seferi boyunca önemini iyice arttırmış, geçtiği bölgelerde yarattığı sosyal kargaşa ve toplu

\footnotetext{
118 d'Ohhson, Denizler Imparatoru Cengiz, 167-171.

${ }_{119}$ d'Ohhson, Denizler Imparatoru Cengiz, 171-172.

${ }^{120}$ Gizli Tarih, 192-194.

${ }^{121}$ Spuler, İran Moğolları, 195.
} 
katliamlar hariç tutulduğunda çok kısa bir zaman diliminde büyük bir bölgeyi Moğol nüfuzu içine sokmuştur. Horasan gibi büyük bir bölgeyi iki-üç ay gibi kısa bir zaman diliminde ele geçiren Toluy, Talekan kuşatmasında zor anlar yaşayan Cengiz Han’ın yardımına da yetişmiştir.

Toluy sinirli bir tabiata sahip olup ne Çin Taoistlerine ne de Ön Asya Müslümanlarına en küçük bir müsamaha göstermemiştir. Çin seferi ve batı seferi boyunca kazaen ölen Moğol komutan ve akrabalarını intikam unsuru olarak kullanmış, yüzbinleri bulan büyük katliamlar gerçekleştirmiştir. Merv şehri kuşatmanın başlarında teslim olmuş olmasına, canlarını bağışlayacağına dair söz vermesine rağmen şehir halkını katledilmiştir. Nişâbûr'un ise teslimiyet talebini komutan ve hanedanın damadı Togaçar'ın ölümü nedeniyle reddetmiştir. Babası Cengiz Han'ın bile amanla ele geçirdiği birçok yerin halkını affetmesi göz önünde bulundurulduğunda Toluy'un bu türden hareketleri dikkat çekicidir.

\section{KAYNAKÇA}

Abû'l-Farac, Gregory. Abu'l Farac Tarihi C. II. çev. Ö. Riza Doğrul. Ankara: Türk Tarih Kurumu, 2. Basım, 1987.

Aka, İsmail. "Mirza Şahruh Zamanında Timurlularda İmar Faaliyetleri”. Belleten 48 (Ocak-Nisan 1984), 285297.

Aka, İsmail. "Şâhruh”. Türkiye Diyanet Vakfi İslâm Ansiklopedisi. 38/295. İstanbul: TDV Yayınları, 2010.

Atwood, Christopher P. Encyclopedia of Mongolia and the Mongol Empire. New York: Fact On File Inc., 1. Basim, 2004.

Aydınlı, Osman. "Semerkant". Türkiye Diyanet Vakfı İslam Ansiklopedisi. 36/484-486. İstanbul: TDV Yayınları, 2009.

Aykut, A. Said. "İbn Battûta”. Türkiye Diyanet Vakfi İslâm Ansiklopedisi. 19/361-368. İstanbul: TDV Yayınları, 1999.

Bayraktar, Mehmet Faruk. "Zernûcî”. Türkiye Diyanet Vakfi İslâm Ansiklopedisi. 44/294-295. İstanbul: TDV Yayınları, 2013.

Bozkurt, Nebi. "İpek Yolu”. Türkiye Diyanet Vakfi İslâm Ansiklopedisi. 22/369-373. İstanbul: TDV Yayınları, 2000.

Britannica, Encyclopedia Britannica. "Hindu Kush". (Erişim Tarihi: 02.05.2020). http://www.iranicaonline.org/articles/hindu-kush

Buell, Paul D. Historical Dictionary of the Mongol World Empire. Maryland and Oxford: The Scarecrow Press, 1. Basim, 2003.

Cahun, Leon. Asya Tarihine Giriş, Kökenlerden $1405^{\prime}$ e Türkler ve Moğollar. çev. S. İnan Kaya. İstanbul: Seç Yayın Dağıtım, 1. Basım, 2006.

Cüveynî, Alaaddin Ata Melik. Tarih-i Cihan Güssa. çev. Mürsel Öztürk. Ankara: Türk Tarih Kurumu, 1. Basım, 2013.

D’ohhson, A. Konstantin. Moğol Tarihi, Denizler Imparatoru Cengiz. çev. Bahadır Apaydın. İstanbul: Nesnel Yayınları, 1. Basım, 2008.

Dardess, John W., "From Mongol Empire to Yüan Dynasty: Changing Forms of Imperial Rule in Mongolia and Central Asia", The History of Mongolia Volume I The Pre-Chinggisid Era Chinggis Khan and the Mongol Empire, ed. David Sneath \& Christopher Kaplonski. 358-389. Folkestone (UK): Global Oriental, 1. Basım, 2010.

Deniz, Bekir. “İpek Yolu Üzerinde Bulunan Eski Türk Şehirleri”. İpek Yolunda Türk Kültür Mirası. haz. Fahri Atasoy. 381-425. Ankara: Türk Yurdu Yayınları, 1. Basım, 2014.

Gürbüz, Meryem. "Tekiş, Aleaddin”. Türkiye Diyanet Vakfı İslâm Ansiklopedisi. 40/364-365. İstanbul: TDV Yayınları, 2011.

Hudud/Minorsky. "The Regions of the World" A Persian Geography 372 A.H.- 982 A.D. trans. V. Minorsky. Cambridge (England): Cambridge University Press, 1. Basım, 1982. 
İbn Battûta. İbn Battûta Seyahatnamesi. haz. Mümin Çevik. İstanbul: Bilge Kültür Sanat, 2. Basım, 2015.

İbn Hurdazbih. Yollar ve Ülkeler Kitabı. çev. Murat Ağarı. İstanbul: Kitabevi Yayınları, 1. Basım, 2008.

İbnu'l-Esîr. el-Kâmil fi 't-ta'rih C. 12. çev. A. Özaydın. İstanbul: Bahar Yayınları, 1. Basım, 1991.

İsakov, Abdrasul. Kırgız-Moğol İlişkileri (IX.-XV. Yüzyıl). Ankara: Ankara Üniversitesi, Sosyal Bilimler Enstitüsü, Doktora Tezi, 2014.

Kafesoğlu, İbrahim. Türk Milli Kültürü. İstanbul: Ötüken Yayınları, 42. Basım, 1998.

Konukçu, Enver. "Beyhak". Türkiye Diyanet Vakfi İslâm Ansiklopedisi. 6/57-58. İstanbul: TDV Yayınları, 1992.

Konukçu, Enver. "Gazne”. Türkiye Diyanet Vakfi İslâm Ansiklopedisi. 13/479-480. İstanbul: TDV Yayınları, 1996.

Kurtuluş, Rıza. "Tûs”. Türkiye Diyanet Vakfi İslâm Ansiklopedisi. 41/431-432. İstanbul: TDV Yayınları, 2012.

Lamb, Harold. Moğollar'ın Efendisi Cengiz Han. İstanbul: İlgi Kültür Sanat Yayınları, 1. Basım, 2006.

Lessing, Ferdinand D. Mongolian-English Dictionary. Berkeley and Los Angeles: University of California Press, 1. Basim, 1960.

Merçil, Erdoğan. "Şahne”. Türkiye Diyanet Vakfı İslâm Ansiklopedisi. 38/292-293. İstanbul: TDV Yayınları, 2010.

Minhâc-1 Sirâc el-Cûzcânî. Tabakât-l Nâsirî Moğol İstilasina Dair Kayttlar. çev. Mustafa Uyar. İstanbul: Ötüken Yayınevi, 1. Basım, 2016.

Moğollar'ın Gizli Tarihi 1. Tercüme. çev. Ahmet Temir. Ankara: Türk Tarih Kurumu, 2. Basım, 1986.

Muhammedcanov, Abdullah. "Tirmiz”. Türkiye Diyanet Vakfi İslâm Ansiklopedisi. 41/200-202. İstanbul: TDV Yayınları, 2012.

NJ, Nanjing. "The Foundations Laid in the Six Dynsties". (Erişim Tarihi:28.03.2020). http://english.nanjing.gov.cn/

Ocak, Sümeyra - Doğanay, Aziz. "İslam Mimarîsinde Mezhep Etkisi: Fas Câmileri Örneğì". İstem 33 (Haziran 2019), 89-109.

Özaydın, Abdülkerim. "Cend”. Türkiye Diyanet Vakfi İslâm Ansiklopedisi. 7/359-360. İstanbul, TDV Yayınları, 1993.

Özaydın, Abdülkerim. "Muhammed b. Tekiş". Türkiye Diyanet Vakfi İslâm Ansiklopedisi. 30/364-365. İstanbul: TDV Yayınları, 2005.

Özcan, Azmi. "Sind". Türkiye Diyanet Vakfi İslâm Ansiklopedisi. 37/242-244. İstanbul: TDV Yayınları, 2009.

Özen, Şükrü. "Kâdılkudât". Türkiye Diyanet Vakfi İslâm Ansiklopedisi. 24/77-82. İstanbul: TDV Yayınları, 2001.

Özgüdenli, Osman Gazi. "Nîşâbur”. Türkiye Diyanet Vakfi İslâm Ansiklopedisi. 33/149-151. İstanbul: TDV Yayınları, 2007, 149-151.

Özgüdenli, Osman Gazi. "Sîstan". Türkiye Diyanet Vakfi İslâm Ansiklopedisi. 37/274-276. İstanbul: TDV Yayınları, 2009. 274-276.

Özgüdenli, Osman Gazi. "Moğollar”. Türkiye Diyanet Vakfi İslâm Ansiklopedisi. 30/225-229. İstanbul: TDV Yayınları, 2005.

Peers, Chris. Genghis Khan and the Mongol War Machine. Barnsley (England): Pen \& Sword Military, 1. Basım, 2015.

Polo, Marco. "Dünyanın Hikâye Edilişi, Harikalar Kitabı”. çev. Işık Ergüden - Z. Zühre İlkgelen. İstanbul: Ötüken Yayınevi, 1. Basım, 2019.

Reşîdüddin Fazlullah Hemadanî. The Successors of Genghis Khan. trans. John Boyle. New York and London: Columbia University Press, 1. Basim, 1971.

Sayan, Yüksel. "Serahs". Türkiye Diyanet Vakfi İslâm Ansiklopedisi. 18/539-542. İstanbul: TDV Yayınları, 2009. 
Sneath, David. The Headless State, Aristocratic Orders, Kinship Society, Misrepresentations of Nomadic Inner Asia. New York: Columbia University Press, 1. Basım, 2007.

Spuler, Bertold. İan Moğollar’’ Siyaset, İdare ve Kültür İlhanlılar Devri (1220-1350). çev. Cemal Köprülü. Ankara: Türk Tarih Kurumu, 1. Basım, 1957.

Sümer, Faruk. "Türkmenler”. Türkiye Diyanet Vakfi İslâm Ansiklopedisi. 41/607-611. İstanbul: TDV Yayınları, 2012.

Taneri, Aydın. “Celâleddin Hârzimşah”. Türkiye Diyanet Vakfi İslâm Ansiklopedisi. 7/248-250. İstanbul: TDV Yayınları, 1993.

Taneri, Aydın. "Gürgenç”. Türkiye Diyanet Vakfi İslâm Ansiklopedisi. 14/321-323. İstanbul: TDV Yayınları, 1996.

Uslu, Recep. "Herat”. Türkiye Diyanet Vakfi İslâm Ansiklopedisi. 17/215-218. İstanbul: TDV Yayınları, 1998.

Uyar, Mustafa. Illhanlı (İran Moğolları) Devleti’nin Askerî Teşkilâtı (Ortaçă̆ Moğol Ordularında Gelenek ve Dönüşüm). Ankara: Türk Tarih Kurumu, 1. Basım, 2020.

Vladimirtsov, B. Y. Moğollar'ın İçtimâ̂ Teşkilâtı, Moğol Göçebe Feodalizmi. çev. Abdülkadir İnan. Ankara: Türk Tarih Kurumu, 3. Basım, 1995.

Yazıcı, Tahsin. "Belh”. Türkiye Diyanet Vakfı İslâm Ansiklopedisi. 5/410-411. İstanbul: TDV Yayınları, 1992.

Yuvalı, Abdulkadir. Ilhanlılar Tarihi I. Kuruluş Devri. Kayseri: Erciyes Üniversitesi Yayınları, 2. Basım, 1994. 